\title{
Regionale mikrotermometriese databasis vir die Proterosoïese gesteentes van die Noordwes-Kaap
}

\author{
A.E. Schoch*, E. Klatt en D. Elsmere \\ Dept. Geologie, Universiteit van die Oranje-Vrystaat, Posbus 339, Bloemfontein 9300 \\ Ontrang 18 Mei 1990; aanuar 6 September 1990
}

OPSOMMING

Die resultate van vloeistofinsluitselstudies van die Proterosol̈ese gesteentes van die Noordwes-Kaap toon aan dat vlugtige bestanddele wat deelgeneem het aan die belangrikste laat-tot natektoniese geologiese prosesse in die Namakwa- mobiele gordel, eiesoortige kenmerke besit. Daar is 'n breë vloeistof-stamverwantskap wat teenwoordig is op verskillende struktuurterreine ten spyte van moontlik kontrasterende vroeë TD-(temperatuur-druk)-geskiedenisse. Afsonderlike water-en koolstofdioksiedinsluitsels kom wydverspreid voor, maar op so ' $n$ wyse dat daur voor insluitselvorming 'n genetiese verband moes gewees het. Insluitselvorming moes grotendeels plaasgevind het by TD-toestande wat laer is as die TD-waardes van die toepaslike $\mathrm{H}_{2} \mathrm{O}-\mathrm{CO}_{2}$ ontmengingskurwe, onderkant $250-330^{\circ} \mathrm{C}$. Volgens die mikrotermometriese eienskappe van die waterinsluitsels is daar egter twee hoofpopulasies van vloeistof, $n l$. 'n vloeistof met lae saliniteit (2 to $3 \%$ eNaCl) en ' $n$ pekel wat ooreenstem met die modelstelsel $\mathrm{H}_{2} \mathrm{O}-\mathrm{NaCI}(\mathrm{KCI})-\mathrm{CO}_{2}$. Betreklik min koolwaterstowwe en $/$ of stikstof is teenwoordig, maar dit wissel in die koolstofdioksiedinsluitsels vanaf I tot 3 mol. \% eCH (Garies-omgewing) tot $11 \%$ eCH (Augrabies-omgewing). Met hierdie regionale en oorkoepelende vloeistofeienskappe as agtergrond, is dit moontlik om subtiele variasies in vlugtige bestanddele te herken wat geassosieer is met lokale geologiese prosesse, soos ertsafsetting. Die breë mikrotermometriese eienskappe van sulfidiese ertsafsettings te Boksputs (naby Copperton) en Aggeneys, toon dat die vlugtige bestanddele nie soseer lokaal gebuffer was deur die mineraalversamelings van gasheergesteentes nie, maar dat dit onder andere die genetiese toestande tydens ertsvorming reflekteer. Dit is dus in beginsel moontlik om vloeistofinsluitseldata as 'n prospekteerhulp te gebruik in die Proterosö̈ese gesteentes van die Noordwes-Kaap, en as 'n metode om genetiese TD-toestande te rekonstrueer. Hierdie gevolgtrekking geld vir alle ertsafsettings in die Namakwa-mobiele gordel, vanaf laaggebonde ertse (bv. Aggeneys) tot by hidrotermies-mesotermiese afsettings van verskillende tipes (soos afsettings in mafiese metalawas in die omgewing van Copperton, en koperertse in die Koperberg Suite van die Koperdistrik, Namakwaland).

\section{ABSTRACT}

Regional microthermometric data base for the Proterozoic rocks of the Northwestern Cape Province First results from fluid inclusion studies of the Proterozoic rocks of the Northwestern Cape, indicate unique characteristics for the fugitive constituents connected to the most important late to post-tectonic geological processes in the Namaqua mobile belt. A broad fluid consanguinity is present in different structural terranes, in spite of possibly contrasting early PT histories. Discrete aqueous and carbon dioxidic inclusions are ubiquitous but occur in such a fashion that a genetical link prior to entrapment is suggested. Entrapment must mainly have taken place at PT-values below the conditions of the relevant $\mathrm{H}_{2} \mathrm{O}$ $\mathrm{CO}_{2}$ solvus, lower than $250-330^{\circ} \mathrm{C}$. However, two principal populations of fluids could be discerned by aid of the microthermometric properties of the aqueous inclusions, namely a fluid with low salinity (2 to $3 \%$ eNaCI) and a brine which corresponds with the model system $\mathrm{H}_{2} \mathrm{O}-\mathrm{NaCl}-(\mathrm{KCl})-\mathrm{CO}_{2}$. Little hydrocarbons and/or nitrogen are present, varying in the carbon dioxidic inclusions from 1 to 3 mole $\%$ eCH (region around Garies) to $11 \%$ eCH $\mathrm{CH}_{4}$ (Augrabies). With these collective regional fluid-properties as background, it becomes possible to recognize subtle variations associated with local geological processes such as ore deposition. The overall microthermometric properties of sulphidic ore deposits at Boksputs (near Copperton) and Aggeneys, show that the fluids, in the main reflect such aspects as the genetic conditions during ore deposition, rather than local buffering by the mineralogical assemblage of the host rocks. It is therefore possible, in principle, to use fluid inclusion properties of the Proterozoic rocks of the Northwest Cape as a prospecting aid and as a method of genetic PT reconstruction. This conclusion is valid for all ore deposits in the Namaqua Mobile Belt, from stratabound ores (e.g. Aggeneys) to hydrothermal-mesothermal deposits of various types (such as occurrences in mafic metalavas at Boksputs near Copperton and copper ores in the Koperberg Suite of the Copper District, Namaqualand).

\section{INLEIDING}

Vlugtige bestanddele is van groot belang tydens bykans alle geologiese prosesse (ertsvorming, metamorfose, stollingsprosesse, sedimentêre prosesse, vervormingsprosesse). Geologiese navorsingsresultate bevat egter selde feitelike besonderhede oor hierdie aspek, vanweë die gebrek aan opvallende en eenduidige proseseffekte. Die studie van vloeistofinsluitsels lewer inligting oor vlugtige bestanddele

*Outeur aen wie korrespondensie gerig kan word wat deur geen ander ondersoekmetode blootgelê word nie en kan dus, in beginsel, die ontbrekende besonderhede verskaf (goed gedokumenteer in tekste van breë toepassing). ${ }^{1.23}$ Die navorsingsresultate wat hier aangebied word, spruit voort uit 'n projek wat in Junie 1981 met ondersteuning van die WNNR (Koöperatiewe Wetenskaplike Projekte) begin is.

Aangesien geen vorige navorsing oor vloeistofinsluitsels in die studiegebied gedoen is nie was dit nie raadsaam om 
weg te spring met 'n ondersoek van 'n spesifieke sulfidiese ertsafsetting nie. Gebrek aan informasic oor die algemene regionale eienskappe van die gebied sou dit immers baie moeilik maak om lokale ertsverwante variasies in dic eienskappe van vloeistofinsluitsels as anomaal te identifiseer en sinvol te interpreteer.

Die grootste gedeelte van die Noordwes-Kaap word onderlê deur gesteentes van die Namakwa- mobiele gordel. Aangesien die ondersoek van vloeistofinsluitsels baie tydrowend is, is dit nie moontlik om 'n sistematiese studie binne die bestek van 'n paar jaar te voltooi vir so 'n groot gebied nie. Gevolglik is besluit om 'n steekproefmetode te volg, deur te konsentreer op 'n aantal teikengebiede wat tektonies en petrochemies grotendeels van mekaar verskil. Hierdie teikengebiede waarin die monsters geneem is, word getoon in fig.1 (links). Vier van die gebiede sluit ertsdistrikte in, waarvan een ekonomies is (Aggeneys). Die subekonomiese afsettings sluit die omgewing van Boksputs in (fig. 1 , regs). Sedertdien is ook subekonomiese erts by Augrabies $^{4}$ ontdek.

Die doelwitte van die projek is om vas te stel of vloeistofinsluitsels in die Namakwa-metamorfe gordel (i) waarneembare eienskappe vertoon wat geassosieer is met (sulfidiese) ertsafsettings; (ii) nuwe lig werp op ertsgenese vir spesifieke ertskonsentrasies; en (iii) algemene karaktertrekke het wat gebruik kan word as 'n prospekteerhulp. Die tussentydse mikpunt is om 'n beeld te verkry van die regionale agtergrondwaardes sodat afwykende eienskappe herken kan word.

\section{METODES}

Die metode van ondersoek behels die neem van monsters in die veld, die petrologiese studie van dunsnitte om geskikte monsters vir vloeistofinsluitselstudies te identifiseer, die voorbereiding van dubbel-gepoleerde diksnitte en die mikrotermometriese studie van die diksnitte. Die mikrotermometriese studie is gedoen met behulp van twee gekalibreerde Chaixmeca-apparate waarvan een gebruik is vir afkoeling $\left(50^{\circ} \mathrm{C}\right.$ tot $\left.-184^{\circ} \mathrm{C}\right)$ en die ander vir verhitting $\left(30^{\circ} \mathrm{C}\right.$ tot $450^{\circ} \mathrm{C}$ ). Eksperimentele vooroordeel is sover moontlik vermy en geen poging is aangewend om (subjektiewe) klassifisering van insluitsels toe te pas nie. Die ondersoekmetode behels die waarneming van faseoorgange in mikroskopiese vlocistofmsluitsels (deursnit 1 $\mu \mathrm{m}$ tot $5 \mu \mathrm{m}$ ), wat voorkom in die rotsvormende mineraal kwarts.

Dit is nie die doel van hierdic projek om spesifieke vloeistofinsluitselpopulasies te identifiseer nie, soos wat byvoorbeeld vereis word vir werk van hoë resolusie (vgl. die klassieke studies van aspekte soos die subtiele verskille tussen insluitselstringe van verskillende oriëntasie, ${ }^{5}$ of soos die fyn variasies wat verertsing beïnvloed op verskillende plekke langs enkelvoudige kwartsare). ${ }^{6}$ Dit is wel waar dat sommige vloeistofinsluitselpopulasies lokaal gebuffer mag wees in terme van die mineraalparageneses van die gasheergesteentes, ${ }^{7}$ maar dit is net so waar dat vlugtige bestanddele groot mobiliteit toon met betrekking tot die inerte elemente en dat daar eintlik geen onfeilbare metodes bestaan waarmee die oorspronklike bewegingsafstande afyelei kan word nie. Baie van die argumente in kontemporêre literatuur ten gunste van lokale buffering (veral vir pogings on die lokale druk-temperatuur-lusse te rekonstrueer), is aanvegbaar. Vir die doel van hierdie ondersoek is daar aanvaar dat die akkumulatiewe vloeistofinsluitselpopulasies komponente van sowel lokale oorsprong (skaal: meters) as van regionale oorsprong (skaal: kilometers) bevat, in wisselende kwantitatiewe verhoudings. Dit is nie vir 'n oor-

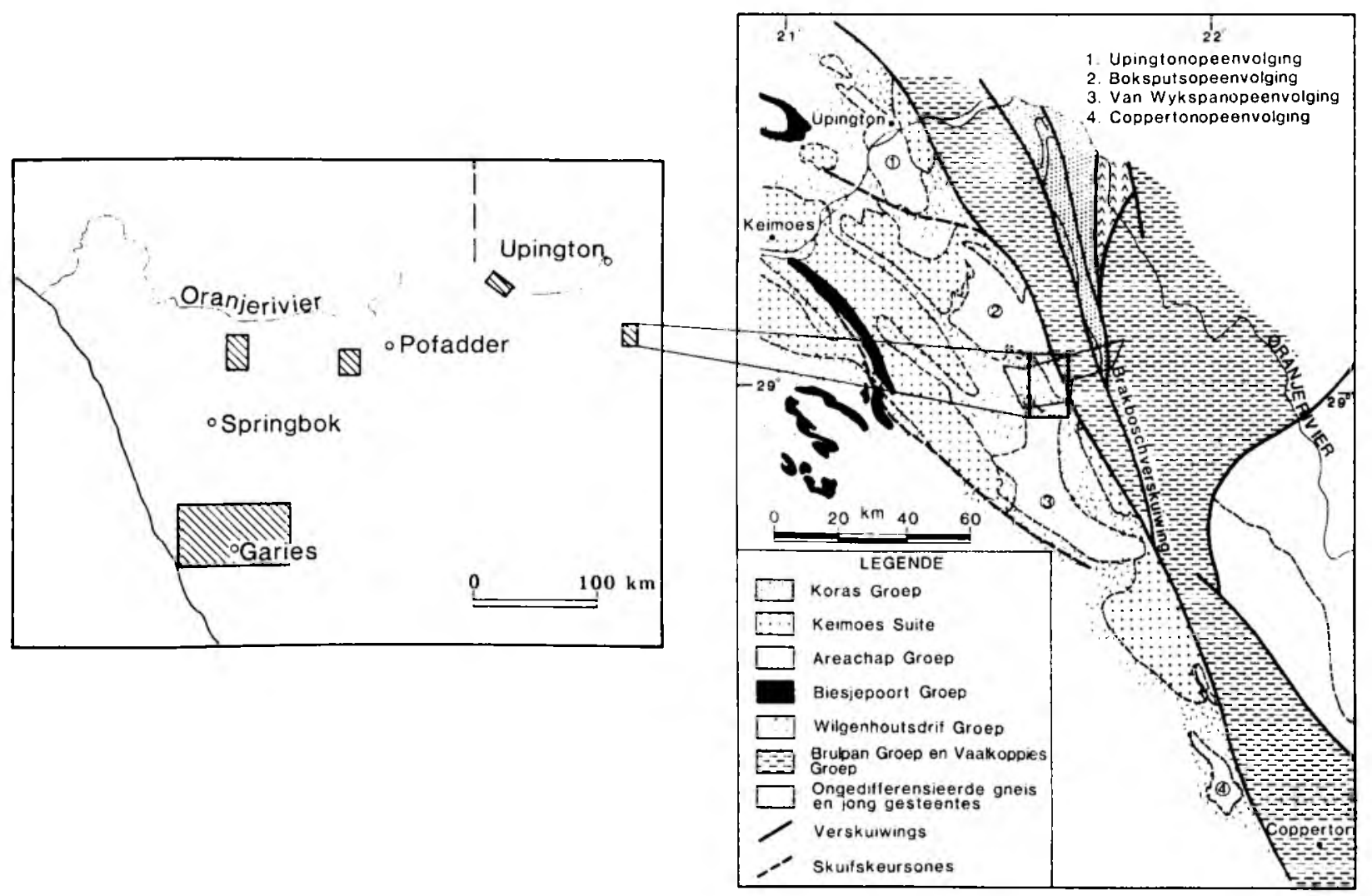

FIGUUR 1: Links: Geselekteerde teikengebiede waarin monsters geneem is (Garies, Geselskapbank, Aggeneys, Augrabies en Boksputs). Regs: Besonderhede oor die geologiese raamwerk van die gebied om Boksputs. ${ }^{49}$ 

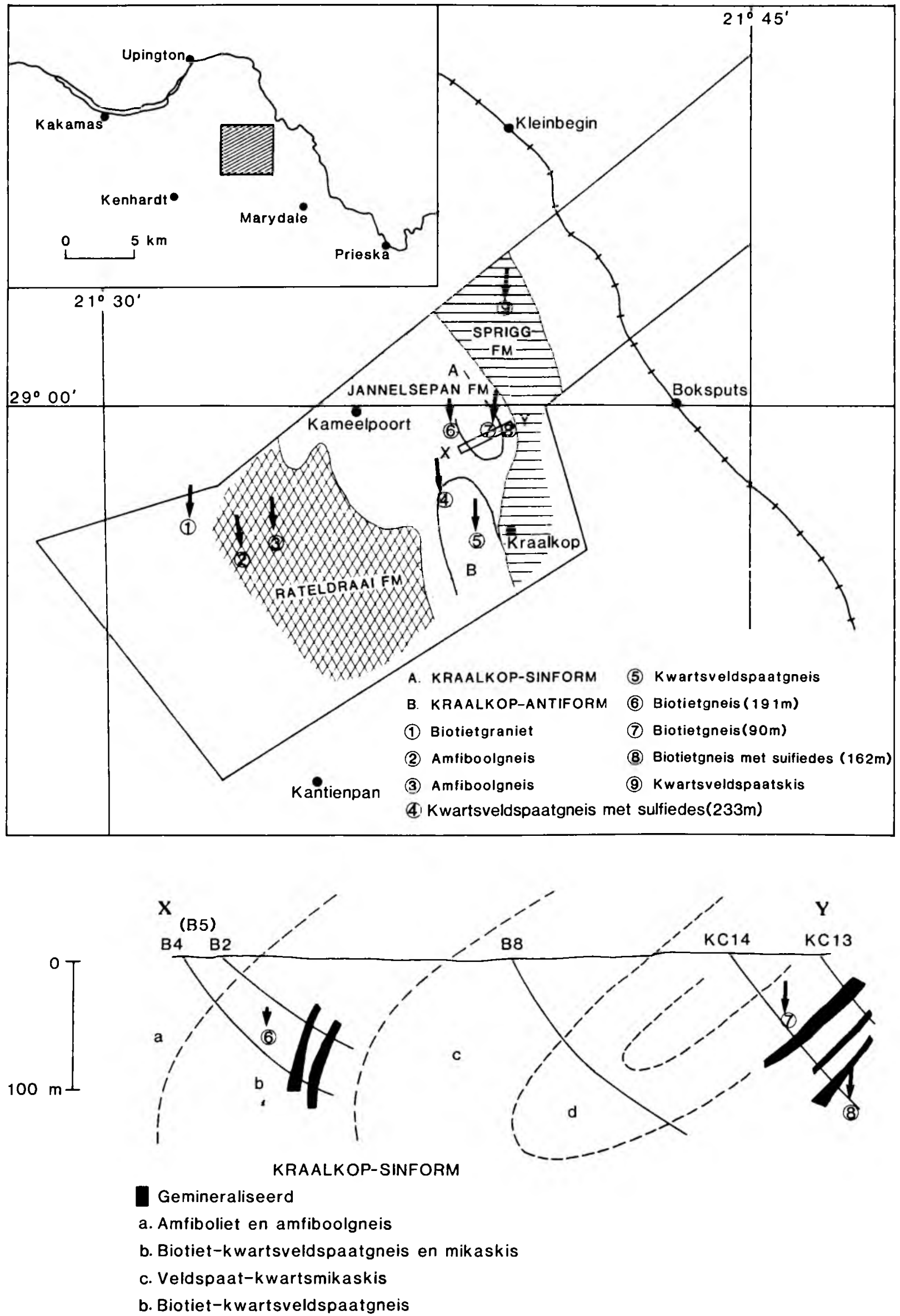

FIGUUR 2: Monsterlokaliteite in die Boksputs-omgewing (omsirkelde getalle), waarvan preparate geselekteer is vir mikrotermometriese ondersoek. Die skakerings wat gebruik word stem ooreen met die drie ingeskrewe formele formasiename (bv. Rateldraai $\mathrm{Fm}=$ Rateldraai Formasie). Die lyn met periodiese merke stel die spoorlyn voor, met die Kleinbegin-en Boksputssylyne aangedui. Op die profiel XY (onder) word die posisie van boorgate aangedui (bv. boorgat B4), waarvan boorkern vir die studie beskikbaar was. 
sigtelike studie beskore om tussen hierdie oorsprongspole te onderskei nie. Hier gaan dit om 'n regionale ondersoek wat as basis kan dien vir latere toegespitste detailstudies.

Metings is gedoen op alle insluitsels wat meetbaar is, sonder seleksie, en alle metings is gedupliseer voordat dit aanvaar is (met herhaalbaarheid van $\pm 0,2^{\circ} \mathrm{C}$ in afkoelingsmodus en $\pm 10^{\circ} \mathrm{C}$ in verhittingsmodus). Geen interpretasie is gedoen voordat daar ' $n$ statisties beduidende aantal lesings per monster beskikbaar was nie, soos aangedui deur goeie piek-tot-agtergrond verhoudings. Die pieke is geinterpreteer in terme van aanvaarde fasestelselbeginsels. ${ }^{8,3,1}$ Meer besonderhede oor geselekteerde monsters is verskaf in projekvorderingsverslae en kongresverrigtinge ${ }^{9,10}$ en 'n M.Sc. verhandeling. " Die lokaliteite van die belangrikste monsters wat vir die studie van 'n gemineraliseerde gebied gebruik is, word in fig. 2 gegee.

Die volgende simbole word gebruik:

\begin{tabular}{|c|c|c|}
\hline $\mathrm{Tm}$ & $=$ & smelttemperatuur, \\
\hline $\operatorname{Tm}_{\mathrm{f}}$ & $=$ & $\begin{array}{l}\text { finale smelttemperatuur (vir gevalle } \\
\text { waar 'n smeltbestek waarneembaar is), }\end{array}$ \\
\hline $\mathrm{Te}$ & $=$ & $\begin{array}{l}\text { eutektiese smelttemperatuur (eerste } \\
\text { smelttemperatuur van 'n smeltbestek), }\end{array}$ \\
\hline $\mathrm{Th}$ & $=$ & $\begin{array}{l}\text { homogeniseringstemperatuur (tempe- } \\
\text { ratuur waarby die gasborrel verdwyn } \\
\text { tydens verhitting), }\end{array}$ \\
\hline
\end{tabular}

\section{BEVINDINGS}

Die regionale mikrotermometriese databasis word opgesom in fig. 3 en 4 . Sedert daar met hierdie ondersoek begin is, het dit uit ander studies duidelik geword dat die Namakwa- mobiele gordel saamgestel is uit 'n groot aantal struktuurterreine wat begrens word deur regionale stootverskuiwings. ${ }^{12,13,14,15,16,17,18,19,20,21}$ Trouens, dit wil voorkom asof struktuurmosaïekverskynsels wêreldwyd 'n kenmerk van Proterosoïese mobiele gordels is. 22.23,24 Dit beteken dat ouer gesteentes bo-op jonger gesteentes kan voorkom en dat elke struktuurterrein 'n eie geohistoriese karakter kan hê. Hierdie diversiteit van geologiese eienskappe geld natuurlik ook vir die vloeistofinsluitselrekords en dit is in beginsel nodig om te onderskei tussen interterrein- en intraterreineffekte.

Die gekose studiegebiede (fig. 1) behoort elkeen aan verskillende struktuurterreine. In die lig hiervan is die groot mate van mikrotermometriese ooreenstemming verbasend (fig. 3, interterreinooreenstemming). Dit impliseer dat die meeste van die vloeistofinsluitsels laat- tot natektonies in ouderdom is (jonger as $1600 \mathrm{Ma}$, miskien selfs $1100 \mathrm{Ma}$ ) en gevorm is nadat al die terreine reeds hul huidige relatiewe posisies bereik het. Ouer vloeistowwe word tussen die oorheersende oorblyfsels verberg en dit is een van die redes waarom die konstruksie van 'n breë databasis nodig is. Oor die algemeen is vloeistofinsluitsels met twee mikroskopies waarneembare vloeistoffases ("dubbelborrels" by kamertemperatuur) betreklik seldsaam in al die bemonsterde gebiede, alhoewel diskrete waterryke en koolstofdioksiedryke insluitsels dikwels in dieselfde monsters voorkom. Dit lyk dus asof die (laat-/natektoniese) vloeistofinsluitsels gevorm het by termiese toestande onderkant die toestande wat gegeld het op die toepaslike $\mathrm{H}_{2} \mathrm{O}-\mathrm{CO}_{2}$ ontmengingskurwes (onderkant $250-300^{\circ} \mathrm{C}^{25}$ of $300-330^{\circ} \mathrm{C}^{26}$ en $300-560^{\circ} \mathrm{C}$ vir pekel). ${ }^{27}$ Die identifisering van klatraatys $\left(\mathrm{CO}_{2} .5,75 \mathrm{H}_{2} \mathrm{O}\right)$ in heelwat van die waterryke insluitsels, dui egter op 'n genetiese verbintenis; die diskrete waterryke en koolstofdioksiedryke insluitsels is waarskynlik die twee vroeg ontmengde endlede van vroeëre hooggraadse en superkritieke $\mathrm{H}_{2} \mathrm{O}-\mathrm{CO}_{2}$ vloeistowwe. Verskeie saliniteitsgrade is teenwoordig, want die klatraat-smelttemperature sprei vanaf $+12^{\circ} \mathrm{C}$ tot laer as $+2^{\circ} \mathrm{C}$ (respektiewelik $0 \% \mathrm{eNaCI}$ en $14 \% \mathrm{eNaCI}$ volgens Collins; ${ }^{28} \mathrm{kyk}$ bv. Tm spektrum vir Augrabies, fig. 3). Daar is soms selfs getuienis van ander klatraattipes soos $\mathrm{CH}_{4} .7 \mathrm{H}_{2} \mathrm{O}$ met $\mathrm{Tm}=15^{\circ} \mathrm{C}$ (vergelyk die Tm spektrum vir Geselskapbank, fig. 3).

Die verskillende waterpopulasies van elke studiegebied word deurgaans oorheers deur vloeistof met 'n lae saliniteit $\left(\operatorname{Tm}_{\mathrm{f}}=-1^{\circ} \mathrm{C}\right.$ tot $-2^{\circ} \mathrm{C}$, fig. 3 ; volgens Roedder ${ }^{2}: 2 \%$ tot $3 \% \mathrm{eNaCI}$ ). Die minimum temperatuur van vorming van hierdie insluitsels varieer tussen $140^{\circ} \mathrm{C}$ en $200^{\circ} \mathrm{C}$ (Th primêre pieke, fig. 3), wat volgens Fisher ${ }^{29}$ en Roedder ${ }^{2}$ digthede verteenwoordig êrens tussen 0,94 en $0,85 \mathrm{~g} / \mathrm{cm}^{3}$. Benewens hierdie varserige waterpopulasie is daar egter ook pekel in elkeen van die studiegebiede teenwoordig $\left(\mathrm{Tm}_{1}\right.$ tussen $-3^{\circ} \mathrm{C}$ en $\left.-21^{\circ} \mathrm{C}\right)$, veral prominent in die Augrabiesgebied (fig. 3). Die waarneming van eerste smelttemperature (Te) by $-20^{\circ} \mathrm{C}$ tot $-21^{\circ} \mathrm{C}$ in die meeste van die monsters dui aan dat die toepaslike modelstelsel $\mathrm{H}_{2} \mathrm{O}$ $\mathrm{NaCl}$ ( $\mathrm{Te}=-21,2^{\circ} \mathrm{C}$ ), of in sommige gevalle miskien $\mathrm{H}_{2} \mathrm{O}-\mathrm{NaCI}-\mathrm{KCI}\left(\mathrm{Te}=-23,5^{\circ} \mathrm{C}\right)$ is. Daar is klaarblyklik ook heelwat van die monsters wat addisionele opgeloste stowwe bevat, alhoewel in 'n ondergeskikte rol (smelttemperature tussen $-21^{\circ} \mathrm{C}$ en $-50^{\circ} \mathrm{C}$, kyk na die histogramme vir Augrabies en Geselskapbank). Sodanige eerste smelttemperature kan verklaar word deur die teenwoordigheid van $\mathrm{MgCI}_{2}$ ( $\mathrm{Te}$ vir $\mathrm{H}_{2} \mathrm{O}-\mathrm{NaCl}-\mathrm{MgCl}_{2}$ is $-35,0^{\circ} \mathrm{C}$ ) en/of $\mathrm{CaCl}_{2}$ ( $\mathrm{Te}$ vir $\mathrm{H}_{2} \mathrm{O}-\mathrm{NaCI}-\mathrm{CaCl}_{2}$ is $-55,0^{\circ} \mathrm{C}$ ). Die stelsel $\mathrm{H}_{2} \mathrm{O}-\mathrm{NaCI}$ is egter aanvaarbaar as 'n eerste benadering van samestelling. Die finale smelttemperature $\left(\mathrm{Tm}_{\mathrm{f}}\right)$ van die pekelpopulasies varieer oorwegend vanaf $-6^{\circ} \mathrm{C}$ tot $-11^{\circ} \mathrm{C}$ (kyk histogramme vir Aggeneys, Boksputs, Augrabies) wat volgens Hall et al. ${ }^{30}$ ooreenstem met $9 \%$ tot $15 \%$ eNaCI. Daar is moontlik vloeistowwe teenwoordig met nog hoër saliniteite bv. in die monsters vanaf Augrabies. Dit is moeilik om die passende homogeniseringstemperature in die komplekse akkumulatiewe histogramme ondubbelsinnig te identifiseer (fig. 3), maar die waardes is skynbaar oorwegend hoër as vir die vloeistofpopulasie met lae saliniteit. Volgens die data van Roedder en Bodnar ${ }^{31}$ is die ooreenstemmende modeldigthede van die pekels dan aansienlik hoër as die digtheid van die meer varswaterpopulasie.

Koolstofdioksiedinsluitsels vertoon in die reël baie breë variasie in fisiese eienskappe, miskien te danke aan aanpassings tydens die geleidelike evolusie vanaf hoëgraadse toestande tot aan die aardoppervlak waar die monster uiteindelik geneem is. Gewoonlik moet 'n baie groot aantal lesings geneem word om die genetiese eienskappe te ontbloot. Baie van die bestudeerde monsters bevat egter nie genoeg koolstofdioksiedinsluitsels om statisties beduidende akkumulatiewe resultate te lewer nie. Voldoende data is versamel vir drie van die studiegebiede (fig. 4). Soos 
verwag kan word in die lig van koolstofdioksiedinsluitsels se sensitiwiteit vir drukverligting, is aansienlike interterreinverskille waarneembaar. Die finale smelttemperatuur van suiwer koolstofdioksied is $\operatorname{Tm}_{\mathrm{r}}=-56,6^{\circ} \mathrm{C}$. en verlaging van hierdie waarde word veroorsaak deur ander, mengbare, vlugtige bestanddele soos koolwaterstowwe en stikstof, wat ook die homogeniseringstemperature (Th) bein- vloed. Volgens die data van Heyen et al. ${ }^{32}$ dui die akkumulatiewe data vir Boksputs $\left(\mathrm{Tm}=-56,6^{\circ} \mathrm{C}\right.$, baie breë Th $=+28^{\circ} \mathrm{C}$ tot $-10^{\circ} \mathrm{C}$ ) op 1 tot $3 \mathrm{~mol} \% \mathrm{eCH}_{4}$, vir Garies $\left(\mathrm{Tm}=-57,6^{\circ} \mathrm{C} \mathrm{Th}=+26\right.$ tot $\left.+16^{\circ} \mathrm{C}\right)$ op 5 tot $11 \% \mathrm{eCH}_{4}$ en vir Augrabies $\left(\mathrm{Tm}=-56.8\right.$ en $-57,8^{\circ} \mathrm{C}$, $\mathrm{Th}=+30$ tot $+6^{\circ} \mathrm{C}$ ) op $24 \% \mathrm{eCH}_{4}$. Volgens die jongste gegewens is die kombinasie van fisiese eienskappe ( $\mathrm{Tm}_{1}$

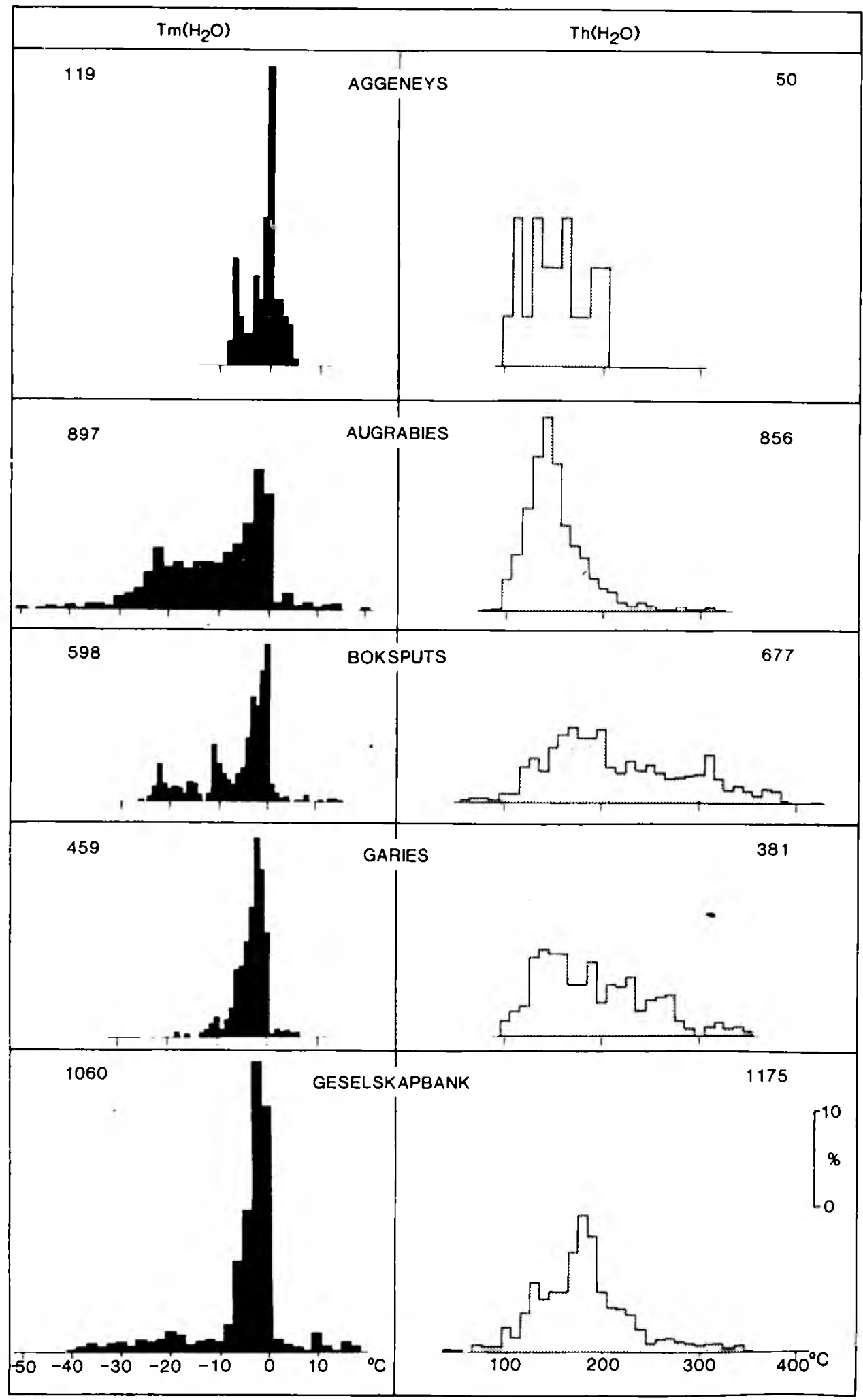

FIGUUR 3: Akkumulatiewe histogramme wat ongeklassifiseerde mikrotermometriese resultate verteenwoordig vir die vyf gebiede wat ondersoek is. Die vertikale skaal word aangegee in terme van frekwenspersent (die persentasieskaal word verskaf in die onderste regterhoek). Die getalle verskaf die aantal gedupliseerde bepalings vir elke gebied. Slegs vloeistofinsluitsels in kwarts word verteenwoordig. Die klassifiseringsbestek is $1^{\circ} \mathrm{C}$ vir die smelttemperatuur-histogramme en $10^{\circ} \mathrm{C}$ vir die homogeniseringshistogramme. 


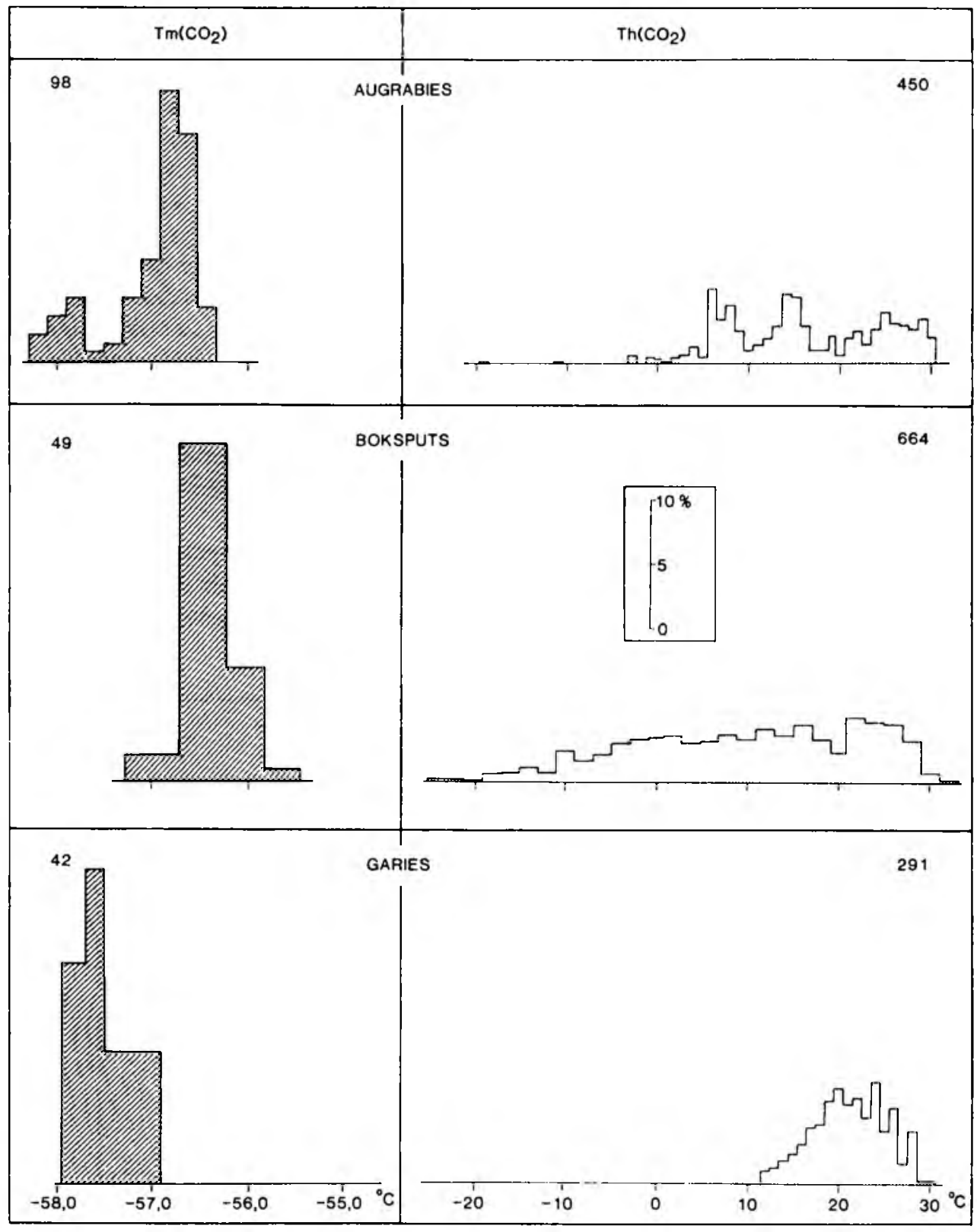

FIGUUR 4: Akkumulatiewe histogramme wat ongeklassifiseerde mikrotermometriese resultate vir koolstofdioksied verteenwoordig vir drie van die vyf gebiede wat ondersoek is. Die vertikale skaal is in terme van frekwenspersent. Die getalle verskaf die aantal gedupliseerde bepalings vir elke gebied. Slegs vloeistofinsluitsels in kwarts word verteenwoordig.

en $\mathrm{Th}$ ) egter dikwels nie eenduidig vir alle moontlike mengsels in die stelsel $\mathrm{CO}_{2}-\mathrm{CH}_{4}-\mathrm{N}_{2}$ nie. ${ }^{8}$ As eerste benadering kan egter voorgestel word dat daar meer $\mathrm{CH}_{4} / \mathrm{N}_{2}$ in die koolstofdioksied van die monsters van Garies as in die monsters van Augrabies of Boksputs teenwoordig is.

Die oorkoepelende mikrotermometriese eienskappe vir die hele Noordwes-Kaap word in fig. 5 opgesom. Ten spyte van die interterreinverskille is 'n breë stamverwantskap waarneembaar en hierdie sintese is juis die eerste doelstelling wat deur hierdie projek nagestreef is. Die "NoordwesKaap-profiel" vertoon sekere onderskeidende kenmerke waarvan sommige reeds vroeër bespreek is (diskrete $\mathrm{H}_{2} \mathrm{O}$ en $\mathrm{CO}_{2}$ insluitsels wat waarskynlik gevorm het tydens die laat- tot natektoniese tydperk). Die waterinsluitsels se samestelling kan oorwegend gemodelleer word met die stelsel $\mathrm{H}_{2} \mathrm{O}-\mathrm{NaCl}$ ( $\mathrm{Te}=-22^{\circ} \mathrm{C}$, fig. 5 bo). Die saliniteit is oorwegend $2-3 \%$ eNaCI (hoë $\mathrm{Tm}_{\mathrm{t}}$ naby $0^{\circ} \mathrm{C}$ ) maar daar is ook sporadies ondergeskikte pekelpopulasies $\left(\mathrm{Tm}_{1}=\right.$ $-4^{\circ} \mathrm{C}$ tot $-11^{\circ} \mathrm{C}$ en laer). Die waterryke insluitsels het 'n genetiese verbintenis met koolstofdioksied, aangesien klatraatys $\left(\mathrm{Tm}>0^{\circ} \mathrm{C}\right)$ dikwels waargeneem word, maar ontmenging het klaarblyklik plaasgevind voor insluitselvorming. Die digthede van die waterpopulasies varieer heelwat, maar word oorwegend verteenwoordig deur homogeniseringstemperature van $140^{\circ} \mathrm{C}$ tot $180^{\circ} \mathrm{C}$ (fig. 5, middel). Daar is egter 'n beduidende persentasie vloeistowwe met hoër temperature (tot so hoog as $\mathrm{Th}=320^{\circ} \mathrm{C}$ ). Die koolstofdioksied is gewoonlik taamlik suiwer (oorwegende smelttemperatuur, $\mathrm{Tm}_{\mathrm{f}}$, naby $-56,6^{\circ} \mathrm{C}$; fig. 5 onder links), maar daar is ook heelwat $\mathrm{C}_{x} \mathrm{H}_{y} / \mathrm{N}_{2}$ teenwoordig $\left(\mathrm{Tm}_{\mathrm{f}}=-57,8^{\circ} \mathrm{C}\right)$. Die digtheid van die koolstofdioksied vertoon 'n baie breë sprei $\left(\mathrm{Th}=30^{\circ} \mathrm{C}\right.$ tot $-5^{\circ} \mathrm{C}$ en selfs so laag as $-10^{\circ} \mathrm{C}$; fig. 5 onder regs). Vir suiwer $\mathrm{CO}_{2}$ sou so 'n sprei 'n digtheidsvariasie vanaf $0,65 \mathrm{~g} / \mathrm{cm}^{3}$ tot $0,98 \mathrm{~g} / \mathrm{cm}^{3}$ aandui (volgens die data van Angus et al.). ${ }^{33}$ Dit is moontlik dat die sprei in koolstofdioksieddigtheid verband hou met die geleidelike di ui:verligting van die bemonsterde gebiede en dat dit as sodanige ii iatektoniese druktemperatuur- 
kontinuum verteenwoordig. Die Th-waardes varieer egter nie ewe breed in al die gebiede nie (fig. 4), sodat die genetiese toestande tydens die laaste metamorfose/metasomatose steeds waaneembaar behoort te wees.

Aangesien mikrotermometriese sinteses vir groot gebiede selde aangepak word, $34,35,36,37,38$ kan geargumenteer word dat 'n breë akkumulatiewe vloeistofinsluitselprofiel altyd dieselfde behoort te wees vir vergelykbare terreine, indien genoeg lesings geneem is. Om hierdie rede is besluit om die resultate vir die Noordwes-Kaap (gedeelte van die Namakwa-mobiele gordel), te vergelyk met resultate vir 'n onverwante mobiele gordel in 'n ander wêrelddeel (die gneise van Finland, vervorm tydens die Kareliese Orogenie, $2100-1900 \mathrm{Ma}){ }^{39,40}$ Die resultate van die vergelyking word in fig. 6 opgesom. Dit is duidelik dat die twee gebiede op mikrotermometriese vlak hemelsbreed verskil. Die Finse vloeistowwe se saliniteite is oorwegend hoër en die digthede heelwat meer as vir die van die vloeistowwe van die Noordwes-Kaap (boonste twee histogramme, fig. 6); die Finse koolstofdioksied is ook baie meer onsuiwer en het baie hoër digthede (onderste twee histogramme, fig. 6). Die regionale mikrotermometriese profiel waaroor hierdie verslag hoofsaaklik handel (fig. 5), is klaarblyklik nie bloot 'n vae algemeenheid wat op enige groot streek van toepassing sou wees nie, maar verteenwoordig eienskappe wat tipies van die Noordwes-Kaap is.

Ons het dus nou die verlangde agtergrondeienskappe waarteen lokale afwykings, soos vloeistowwe wat gemoeid was met ertsvorming of ertsveredeling, geïnterpreteer kan word. In Boesmanland is daar belangrike laaggebonde ertsafsettings (Aggeneys, Gamsberg) en dit bly nog steeds 'n vraag of mikrotermometriese variasies op formasievlak nie veel groter is as die subtiele ertsverwante effekte waarna ons soek nie. Om hierdie rede is dit nodig om te kyk na die gemiddelde interformasie-eienskappe (keuse: die Boesmanland Groep te Geselskapbank), voordat daar aandag gegee word aan erts.

Die stratigrafiese opeenvolging van die hoogsvervormde en gemetamorfoseerde sedimentêre gesteentes van Boesmanland is in die afgelope paar jaar geleidelik uitgepluis

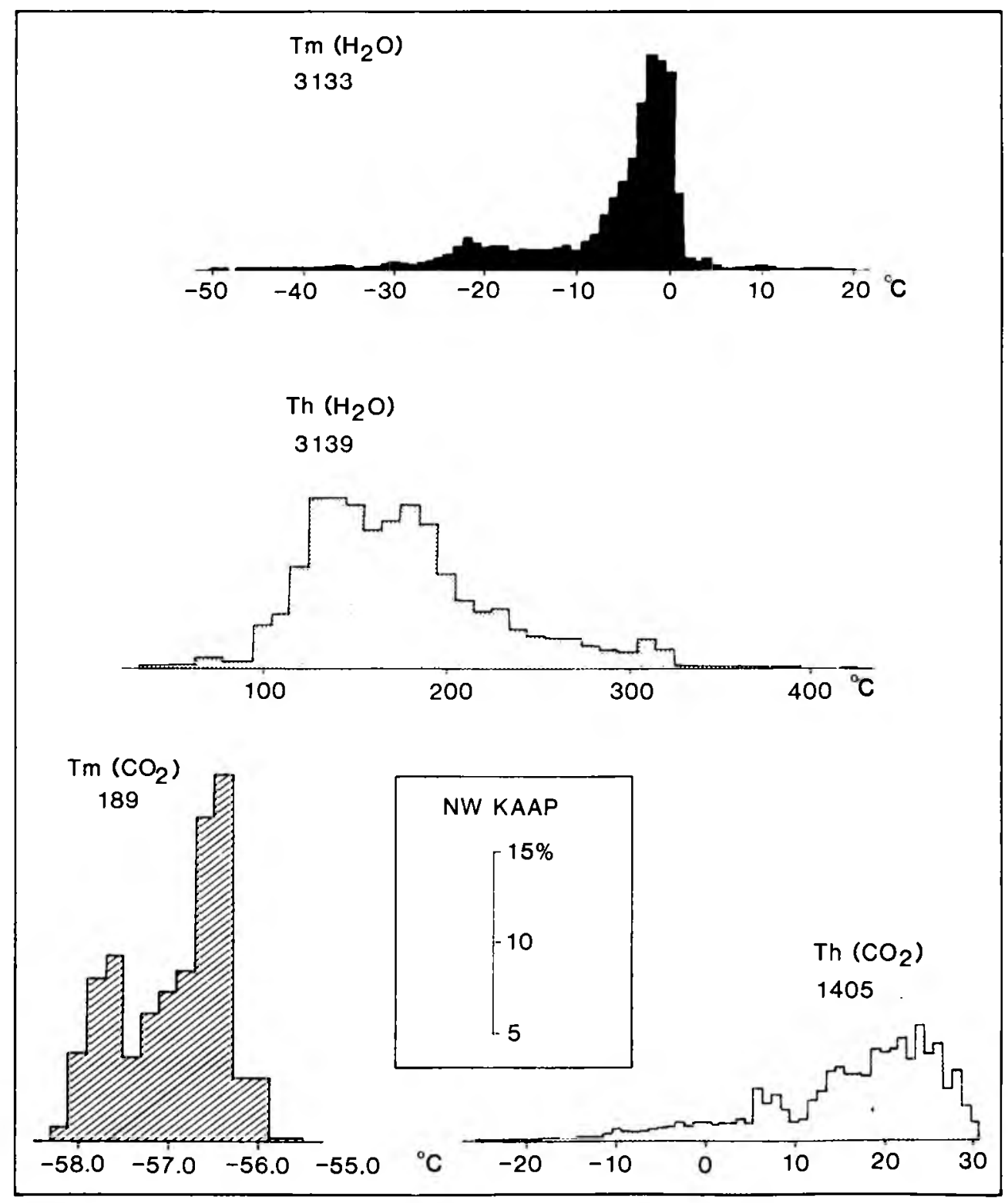

FIGUUR 5: Akkumulatiewe histogramme van ongeklassifiseerde mikrotermometriese resultate vir al die studiegebiede. Die vertikale skaal is in terme van frekwenspersent. Die besonderhede vir afsonderlike studiegebiede word verskaf in fig. 3 en fig. 4. Hierdie is die eienskappe van die "Noordwes-Kaap-profiel". 


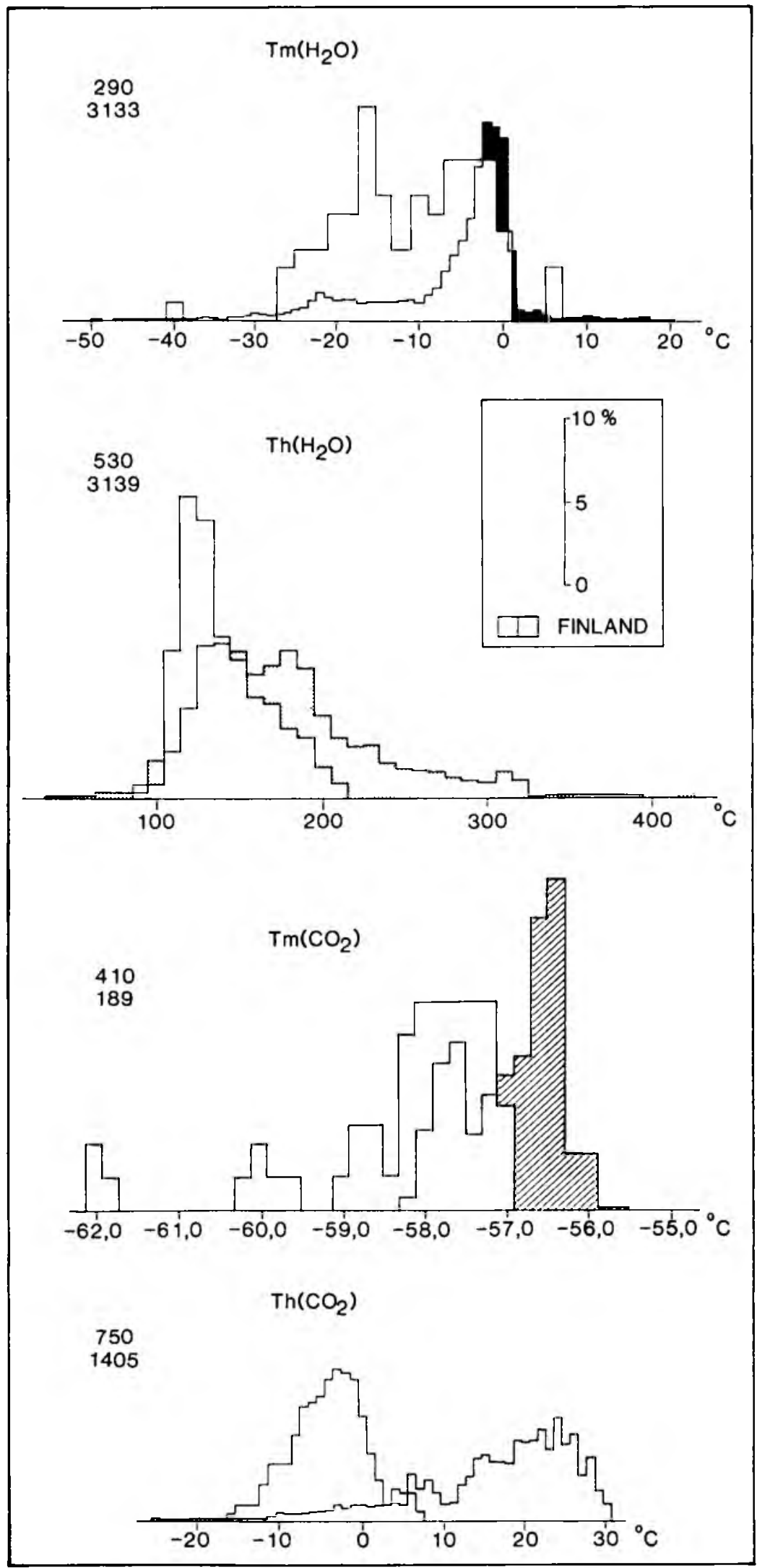

FIGUUR 6: Vergelyking tussen akkumulatiewe mikrotermometriese resultate vir die Namakwa-mobiele gordel (NoordwesKaap; histogram-ornamentasie dieselfde as in fig. 5) en die sentrale mobiele gordel van Finland (histogramme ongeornamenteer, of geornamenteer met baie fyn stippels). Die vertikale skaal is in terme van frekwenspersent. Van die twee getalle by elke histogram verteenwoordig die boonste een die aantal gedupliseerde lesings vir monsters van Finland en die onderste getal die ooreenstemmende waarde vir die Noordwes-Kaap (soos in fig. 5). 


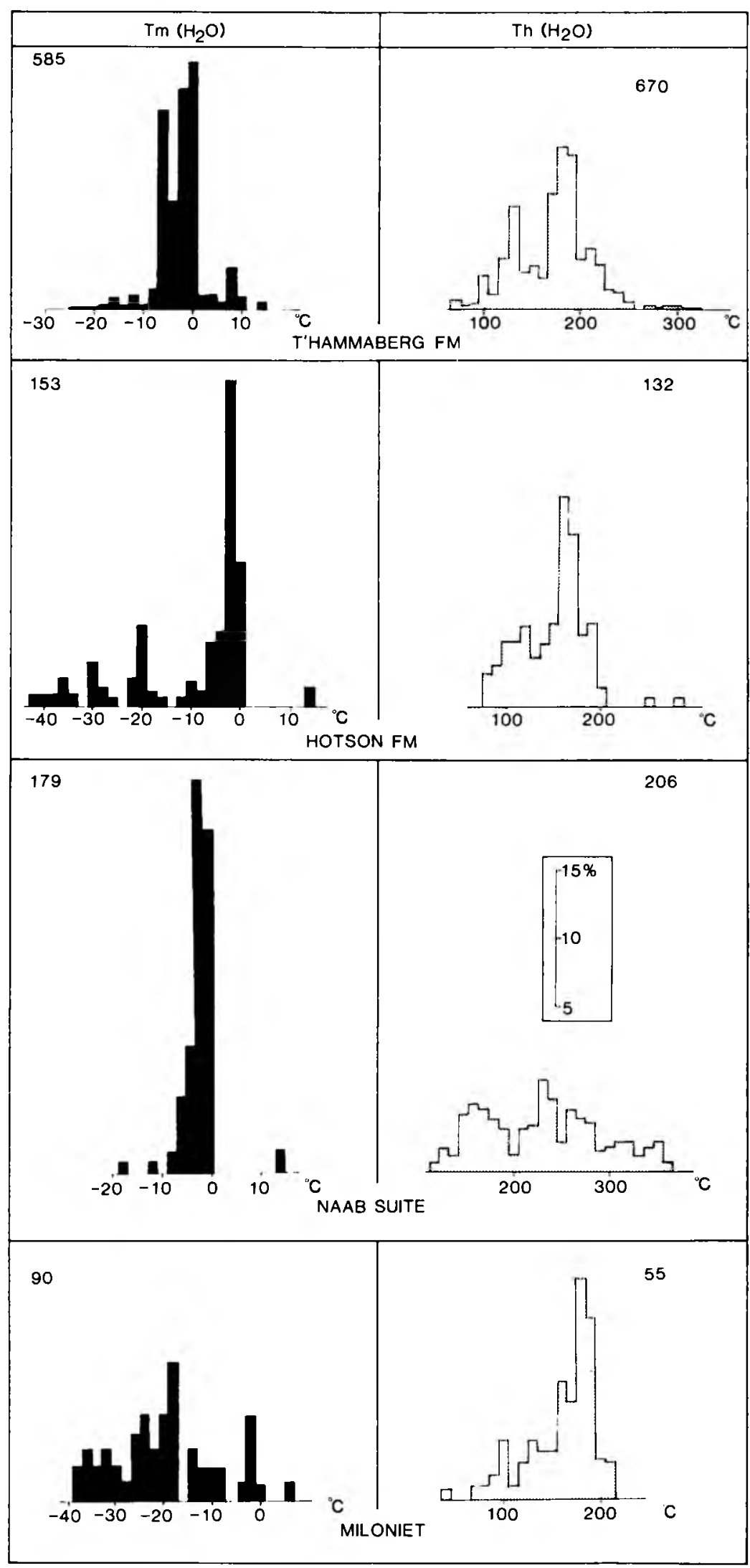

FIGUUR 7: Akkumulatiewe histogramme wat ongeklassifiseerde mikrotermometriese resultate vir verskillende formasies in die Geselskaphankgebied verteenwoordig. Die gesamentlike data word in fig. 3 gegee. Die vertikale skaal is in terme van frekwenspersent. Die getalle verskaf die aantal gedupliseerde bepalings vir elke formasie of groepering. Slegs vloeistofinsluitsels in kwarts is verteenwoordig. 
(die Boesmanland Groep). ${ }^{13,41.20,42}$ Die gebied om Geselskapbank is een van die gebiede wat eerste klaar gekarteer was. ${ }^{43,44}$ Die oorkoepelende mikrotermometriese resultate vir hierdie gebied (fig. 3) word nou in besonderhede aangebied (fig. 7). Dit is duidelik dat die interformasieverskille aansienlik is, maar dat die vloeistofinsluitsels van die Hotson Formasie nogal ooreenstem met die gegewens vir miloniet ('n breë milonietsone geassosieerd met die regionale Naab-stootverskuiwing). ${ }^{45,18}$ Dit is vandag bekend dat die laaggebonde sulfidiese erts van Aggeneys en Gams juis met die Hotson Formasie verband hou ${ }^{13,41.45 .46,47}$ (vgl. die Beenbreek Formasie van Strydom). ${ }^{43}$ Die verskillende formasies vertoon wel herkenbare eiesoortige eienskappe en die bydrae van die Hotson Formasie tot die eienskappe van die hele Geselskapbank-gebied (fig. 3) kan nou maklik herken word. Dit is egter moontlik om lokale ertsverwante effekte uit te ken (vergelyk die resultate vir Aggeneys, fig. 3, met die resultate vir die Hotson Formasie te Geselskapbank, fig. 7).
Ten einde die toepassing van mikrotermometrie op 'n spesifieke ertsafsetting in die Noordwes-Kaap te demonstreer, is 'n baie moeilike voorbeeld gekies, 'n subekonomiese afsetting in 'n metalawakompleks naby die spoorweghalte met die naam van Boksputs, noordwes van Copperton (fig. I en 2). Die geologiese besonderhede van hierdie gebied word in twee verhandelings beskryf. ${ }^{48,49}$ Die erts kom hoofsaaklik in gesteentes van die Areachap Opeenvolging voor en is as sodanig met ander welbekende afsettings van moontlike hidrotermiese oorsprong by Copperton en Areachap vergelykbaar (fig. 1).49.50.51 Die Areachap Opcenvolging word in 'n verskeidenheid van metavulkaniese en metasedimentêre stratigrafiese eenhede verdeel, soos die Jannelsepan, Sprigg en Rateldraai Formasies, met 'n reeks van intrusiewe granitiese gneise. Die ertssones word aangetref in die metavulkaniese Jannelsepan Formasie (die Kraalkop antivorm en Kraalkop sinvorm, fig. 2; die Boksputs Formasie van Pretorius) ${ }^{49}$ waarvan die oorspronklike samestelling gevarieer het vanaf basalties tot an-

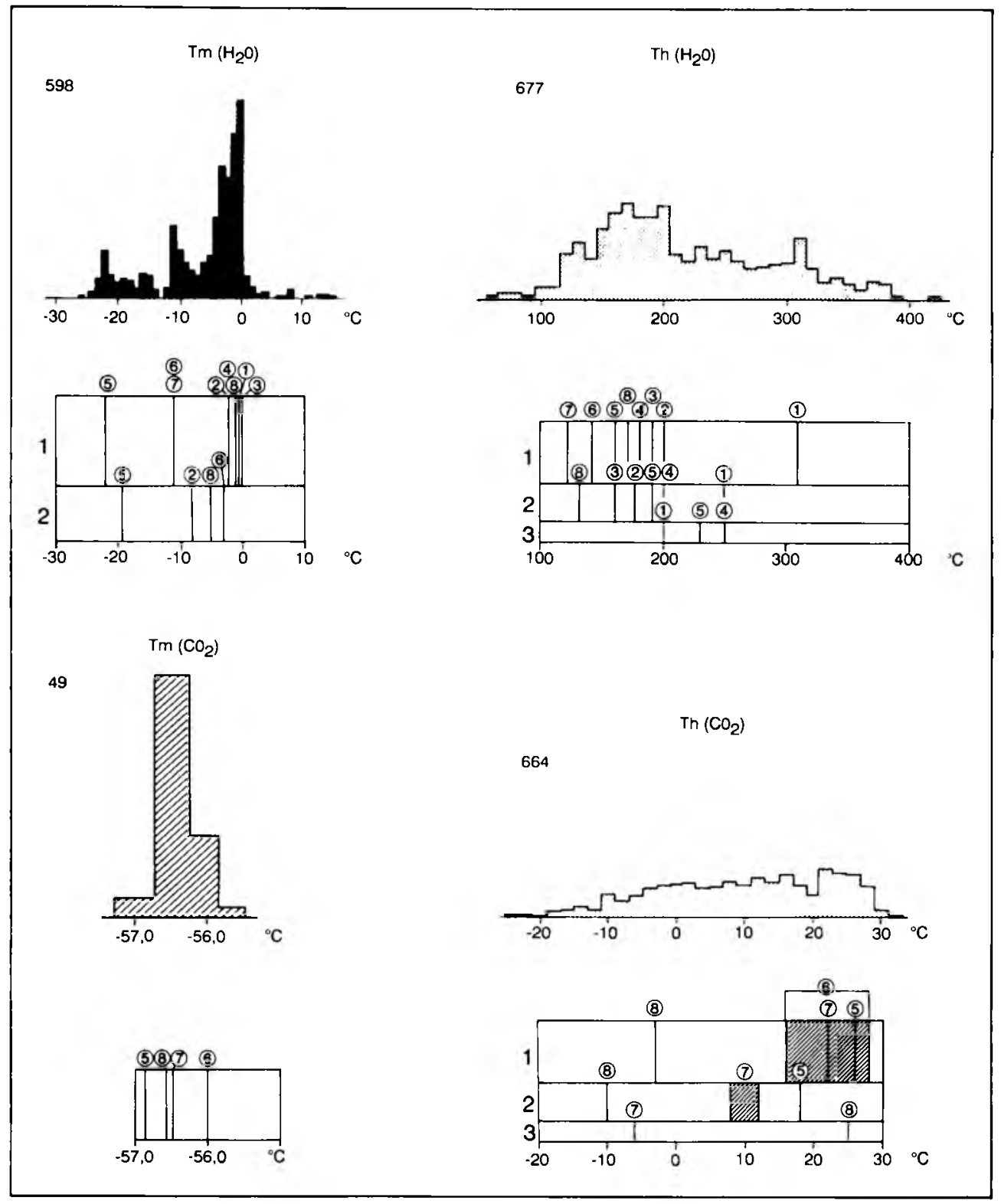

FIGUUR 8: Akkumulatiewe mikrotermometriese resultate vir die Boksputs-gebied. Die getalle verteenwoordig die aantal gedupliseerde bepalings. Slegs vloeistofinsluitsels in kwarts is verteenwoordig. Onder elke histogram word die posisies van pieke vir indiwiduele monsters gegee. Die getalle aan die linkerkante identifiseer die pieke se rangorde $(I=$ primêr, $2=$ sekondêr, 3 = tersiêr). Die getalle wat omsirkel is, verteenwoordig die monsternommers gegee in fig. 2. 
desities en selfs dasities, met bykomende kalksilikaat-gesteentes en ysterryke chert.

Die vloeistofinsluitsels in die ertshoudende monsters vanaf Boksputs is oorwegend baie klein $(<1$ tot $3 \mu \mathrm{m})$ en is baie $y l$ verspreid. Dit is onprakties om ' $n$ mikrotermometriese studie van die kwartsarme metalawas as sodanig te maak. Die beweeglikheid van vlugtige bestanddele maak dit egter moontlik om die nodige informasie te verkry van enige van die ander gesteentes in die omgewing, selfs al is daardie gesteentes nie geneties aan die erts verbonde nie. Die enigste vereiste is dat die studiemonsters gesteentes wat reeds tydens die tydperk(e) van verertsing en/of erts-veredeling bestaan het, moet verteenwoordig. Ná mikroskopiese ondersoek van 'n groot aantal monsters is 'n paar vir mikrotermometriese ondersoek geselekteer (fig. 2). Hierdie monsters verteenwoordig 'n verskeidenheid van gneise uit verskillende formasies van die Areachap Opeenvolging en een intrusiewe graniet.

Die mikrotermometriese resultate vir die uiteenlopende groep monsters vertoon 'n breë variasie, soos wat verwag kan word. Baie meer werk sal gedoen moet word om al die besonderhede van die hidrotermiese geskiedenis uit te pluis, maar algemene eienskappe van die Boksputs-gebied is ontbloot wat met geen ander studiemetode verkry kon gewees het nie"l (fig. 8). Die vloeistofpopulasies is grotendeels onafhanklik van stratigrafiese eenhede en van gasheergesteentetipes (insluitende gegewens vir boorkernmonsters naby aan ertssones). Die breë eienskappe van die "Noordwes-Kaap-profiel" is steeds teenwoordig (fig. 5), maar lokale besonderhede is maklik onderskeibaar (fig. 3 en fig. 4). Waterpopulasies van lae en hoë saliniteit is teenwoordig sowel as oorwegend diskrete en suiwer koolstofdioksied, met 'n breë verspreiding van digthede. In detail is daar baie verskille tussen die verskillende monsters, maar die mees fundamentele gegewens, die termiese waardes van die frekwenspieke en frekwensbestekke, is naby aan mekaar (fig. 8). Die belangrikste smelttemperatuurpieke is tussen $0^{\circ} \mathrm{C}$ en $-10^{\circ} \mathrm{C}\left(\mathrm{Tm}_{\mathrm{f}}\right.$ van die waterryke insluitsels $)$, met ooreenstemmende homogenisering tussen $110^{\circ} \mathrm{C}$ en $200^{\circ} \mathrm{C}$ (Th van die waterryke insluitsels). Vir koolstofdioksiedinsluitsels is die smelttemperatuurpieke tussen $-56^{\circ} \mathrm{C}$ en $-57^{\circ} \mathrm{C}$ (naby aan die teoretiese $\mathrm{Tm}_{1}=$ $-56.6^{\circ} \mathrm{C}$ vir suiwer koolstofdioksied), maar die belangrikste homogeniseringspieke wissel by voorkeur tussen $+15^{\circ} \mathrm{C}$
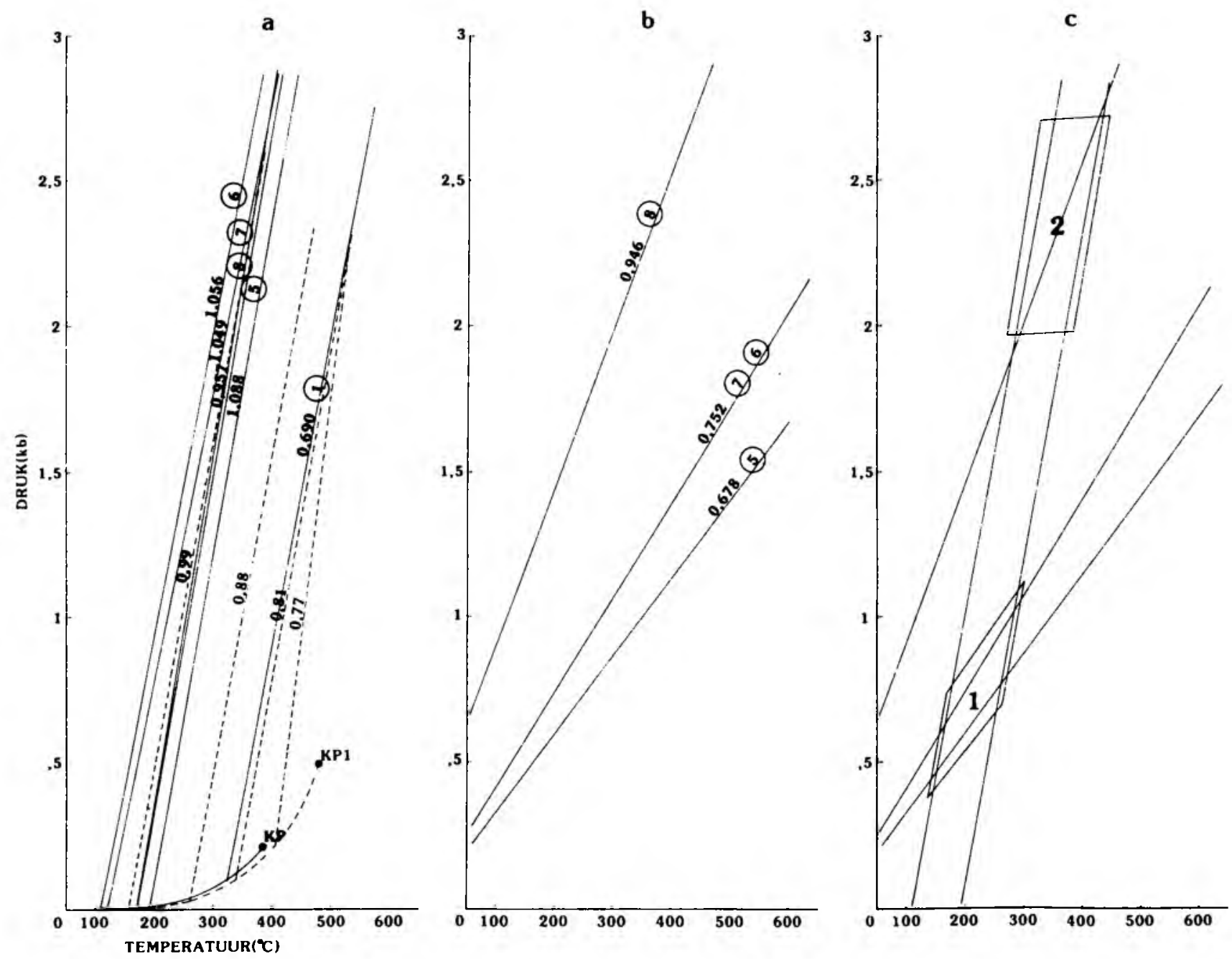

FIGUUR 9: Berekende isochore ${ }^{56}$ van prominente mikrotermometriese pieke vir indiwiduele monsters uit die Boksputs-gebied. Die omsirkelde getalle identifiseer die monsters gegee in fig. 2 en die ander getalle verteenwoordig die afgeleide digthede in $\mathrm{g} / \mathrm{cm}^{3}$. a. Isochore vir waterryke insluitsels (KP=kritieke punt. $\mathrm{KPI}=$ kritieke punt vir water met $\left.10 \% \mathrm{NaCl}\right) . \mathrm{Die}$ harde lyne is isochore vir water met 'n lae saliniteit en die stippellyne is isochore vir water met $10 \% \mathrm{NaCI}$. b. Isochore vir diskrete koolstofdioksiedinsluitsels. $c$. Moontlike ontstaanstoestande vir saambestaande water en koolstofdioksied. Die twee moontlike genetiese populasies is hoogs spekulatief, maar verskaf motivering vir verdere studies. 
tot $+28^{\circ} \mathrm{C}$. Die vormingstoestande word verskaf deur berekende isochore afgelei vanaf die homogeniseringstemperature en samestellingsmodelle (fig. 9). Indien hierdie monovariante toestande gelyktydig waar was vir geneties verwante waterryke insluitsels en koolstofdioksiedinsluitsels, kan invariante parameters afgelei word (die KaljoesnjiKoltoen kriterium), ${ }^{2}$ maar sodanige druktemperatuurwaardes is hoogs spekulatief en het verdere werk vir bevestiging nodig (fig. 10).

Dit is duidelik dat mikrotermometriese ondersoek van besondere monsters wel veel van die lokale hidrotermiese geskiedenis kan ontbloot, selfs in "moeilike" gesteente soos die metalawas van die Areachap Opeenvolging. 'n Vergelyking met die ekonomiese ertsdistrik van Copperton toon interessante ooreenstemmings en kontraste (fig. 11, 3 en 4). Die samestelling van die waterryke vloeistofinsluitsels is baie soortgelyk (Tm spektrums, fig. 11 bo), maar die Copperton-vloeistowwe het oorwegend laer digthede as die Boksputs-vloeistowwe (kyk Th spektrums, fig. 11 middel). Die koolstofdioksiedinsluitsels van Copperton is verbasend min gesprei in terme van digtheid, in vergelyking met die baie breë spektrum vir Boksputs ( $\mathrm{Th}$, fig. 11 onder).

Daar is egter ook ander soorte ertse as hidrotermiese ertse in die Namakwa- mobiele gordel. Die vlugtige bestanddele in sekere hooggraadse gebiede kon in terme van mineraalreaksies gebuffer gewees het ${ }^{7}$, maar hierdie effekte sal net 'n deel van 'n gesteente se vloeistofinsluitselrekord verteenwoordig. Hier gaan dit oor die oorkoepelende mikrotermometriese eienskappe; vir besonderhede op mesoskaal sal spesiale studies gedoen moet word vir elke spesifieke geval. Voorlopige mikrotermometriese resultate vir die barietafsettings van Aggeneys en Gamsberg toon dat die vloeistowwe wat met die bariet geassosieerd is, goed onderskeibaar is van die vloeistowwe in die omgewingsgesteentes (fig. 12). Vergelyk ook die algemene eienskappe van die gasheerformasie, die Hotson Formasie, wat op heeltemal 'n ander plek vasgestel is (Geselskapbank, fig. 7).

Genoeg is gesê om te demonstreer hoe vloeistofinsluitselstudies nuttige informasie oor ertsomgewings in die Noordwes-Kaap kan verskaf. Daar kan op 'n eksotiese noot afgesluit word, betreffende die unieke koperhoudende dioriete van Namakwaland (die Koperberg Suite). $52,53,10.54 .55$ Voorlopige mikrotermometriese gegewens (fig. 13), toon dat die vloeistowwe wat met ertshoudende gesteentes geassosieer is (Koperberg Suite) heelwat verskil van die vloeistowwe wat in omgewingsgesteentes teenwoordig is (soos Concordia-gneis en megabreksie).

\section{DANKBETUIGINGS}

Die WNNR word bedank vir finansiële steun vir die grootste gedeelte van die studie, as deel van die Koöperatiewe Wetenskaplike Projekte (Afdeling Navorsingstegnieke). Die figure is deur A. Felix voorberei en die manuskrip is deur P. Swart getik.

\footnotetext{
VERWYSINGS

I. Hollister, L.S. \& Crawford, M.L. eds. (1981). Short Course in Fluid Inclusions: Applications to Petrology. Short Course Handbook 6. Mineral. Ass. Canada, Calgary. 304 p.

2. Roedder, E. (1984). Fluid Inclusions. Mineral. Soc. America, Reviews in Mineralogy, 12 (Blacksburg, Virginia). 664 p

3. Shepherd, T., Rankin. A.H. \& Alderton, D.H.M. (1985). A Practical Guide to Fluid Inclusion Studies (Blackie, London). 239 p.

4. Saad, A.E. (1987). A petrological study of the tin-tungsten deposit at Renosterkop, Augrabies, Northem Cape Province. Unpubl. M.Sc. diss., Univ. Potchefstroom. $158 \mathrm{p}$.

5. Lespinasse, M. (1989). Tectonic structures and fluid inclusion trails. Abstract, Ecrofi 10 (Tenth conference, European Current Research on Fluid Inclusions), (London) 1, 61.

6. Woods, T.L. Roedder, E. and Bethke, P.M. (1982). Fluid-inclusion data on samples from Creede, Colorado, in relation to mineral paragenesis, U.S. Geol. Surv. Open File Rep., 82-313. 77 p.
}

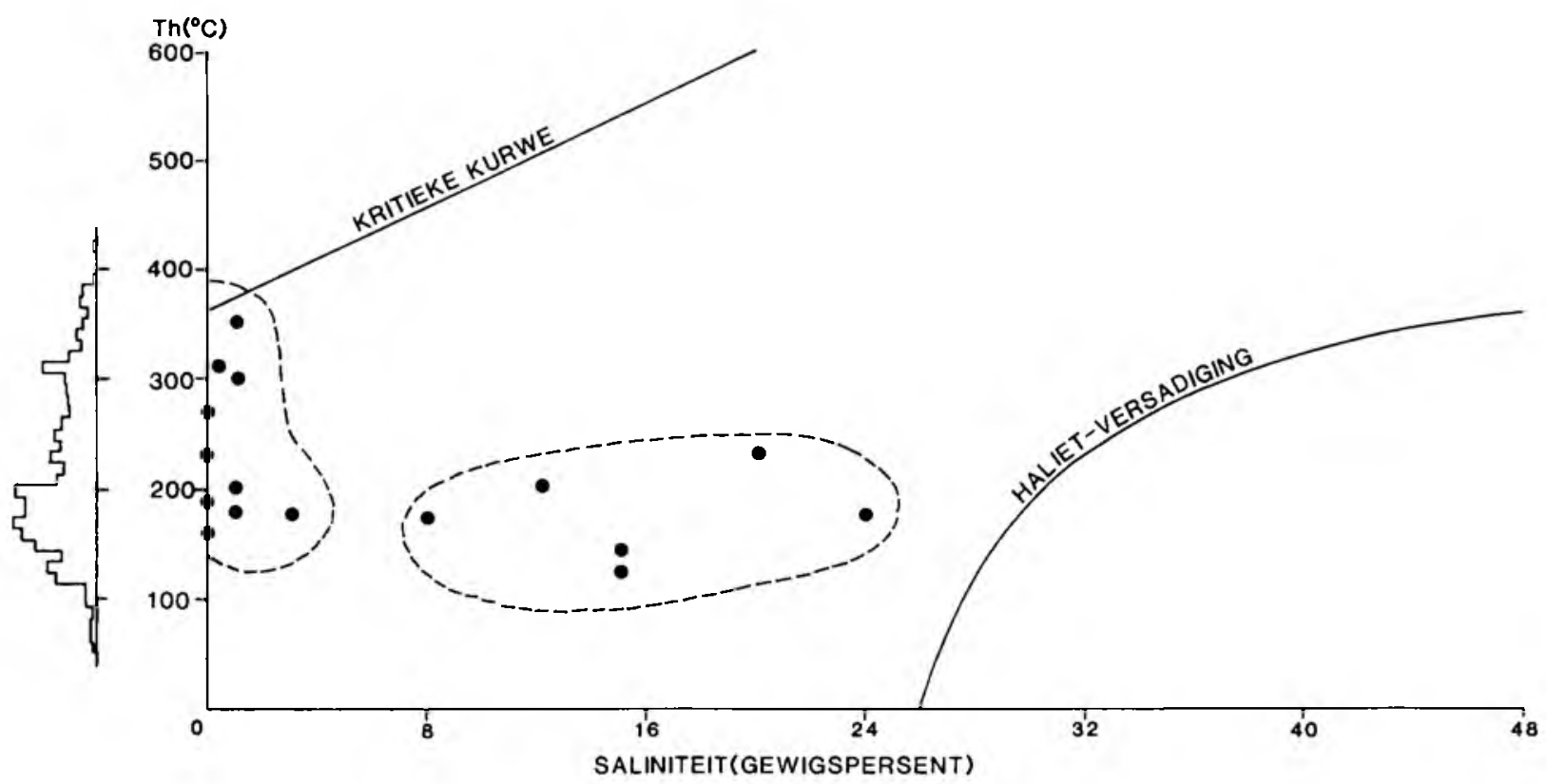

FIGUUR 10: Saliniteitshomogeniseringsdiagram vir 'n aantal vloeistofins/uitsels in verskillende monsters van Boksputs. Die histogram op die linkerkant is die akkumulatiewe homogeniseringsdiagram wat verskaf is in fig. 8. Die saliniteit is afgelei en verteenwoordig \% eNaCl. Die twee populasies wat getoon word, stem ooreen met die twee moontlike genetiese populasies gegee in fig. $9 c$. 


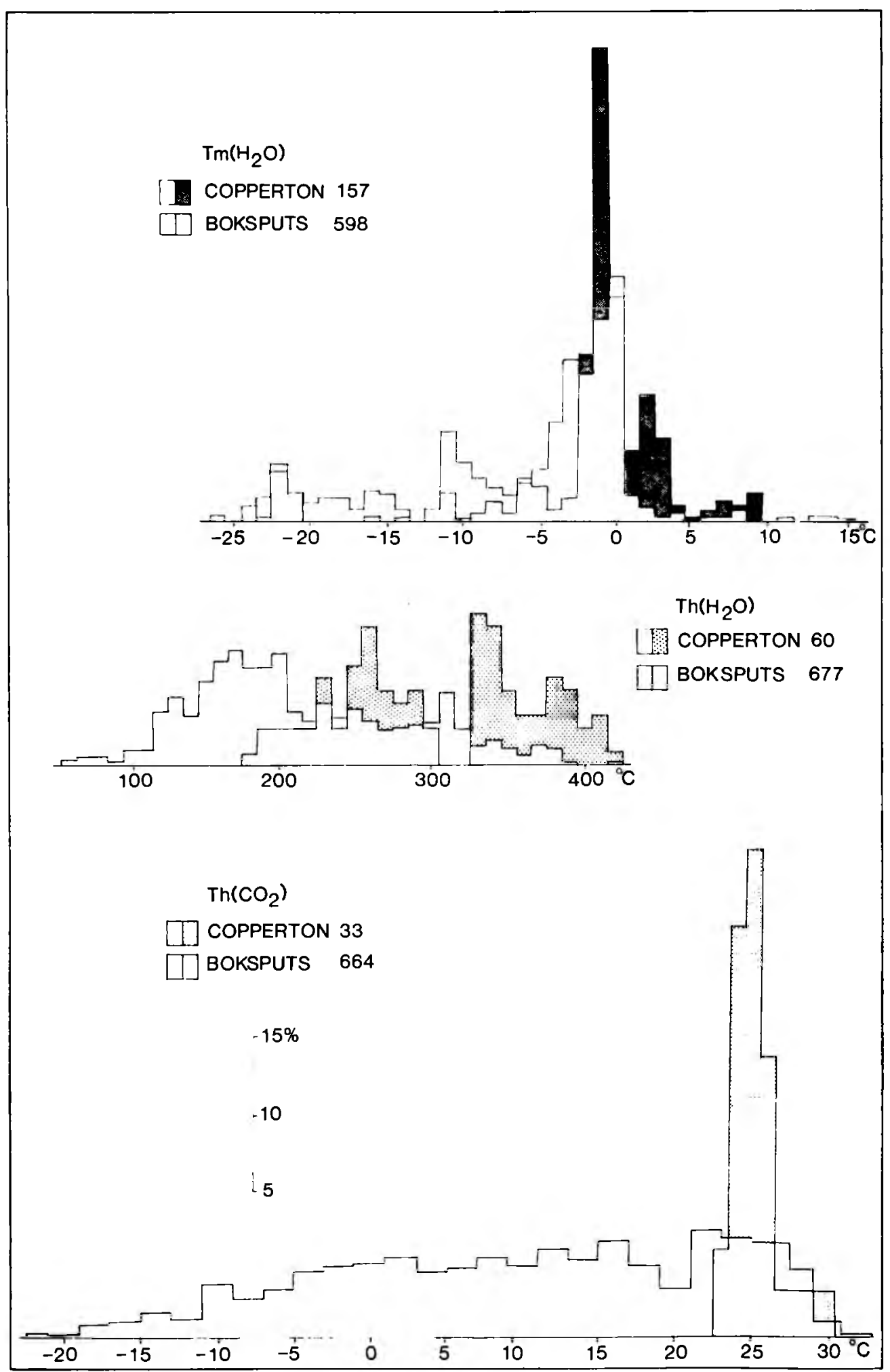

FIGUUR II: Vergelyking tussen akkummulatiewe mikrotermometriese resultate vir die Copperton-ertsafsetting en die Boksputsgebied (kyk fig. 8). Die vertikale skaal is in terme van frekwenspersent. Die getalle verteenwoordig die aantal gedupliseerde lesings. 


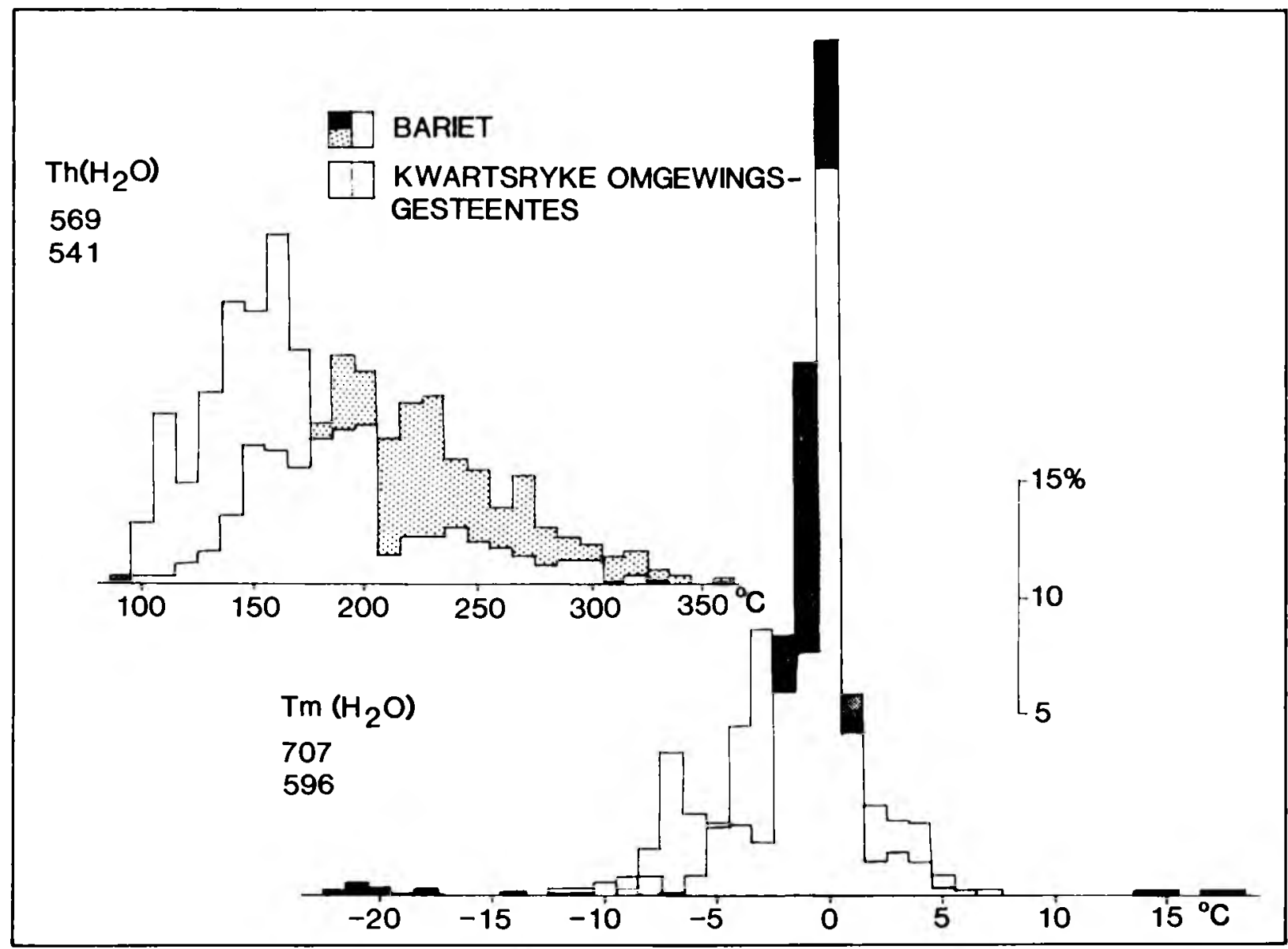

FIGUUR 12: Vergelyking tussen akkumulatiewe mikrotermometriese resultate vir omgewingsgesteentes en barietafsettings in die Hotson Formasie te Aggeneys (Black Mountain) en Gamsberg. Van die twee getalle by elke histogram verteenwoordig die boonste een die aantal gedupliseerde lesings vir bariet en die onderste een die ooreenstemmende waardes vir kwartsryke wandgesteentes en kwartsare.

7. Ashworth, J.R. ed. (1985). Migmatites (Blackie, Glasgow). 302 p.

8. Van den Kerkhof, A.M. (1988). The system $\mathrm{CO}_{2}-\mathrm{CH}_{4}-\mathrm{N}$, in Fluid Inclusions: Theoretical moxielling and geological applications. Thesis, Vrije Universiteit, Amsterdam (Vrije Universiteit-pers, Amsterdam) $206 \mathrm{p}$.

9. Schoch, A.E. Elsmere, D., Cilliers, F.H., Geringer, G.J. \& Pretorius, J.J. (1986). The composition of fluid inclusions in the Boksputs region, Upington and its relationship to sulphide mineralization. Abstract, 2lst Congr. Geol. Soc. S. Afr., (Johannesburg) 1, 867-871.

10. Schoch. A.E. (1989). Fluid inclusion compositions associated with the Koperberg Suite, Namaqualand, South Africa. Abstract, Ecrof 10 (Tenth Conference, European Current Research on Fluid Inclusions), (London) 1, 83 .

11. Elsmere, D. (1987). The characteristics of fluid inclusions in the metamorphites and mineralized rocks of the Boksputs region, Upington. Unpubl. M.Sc. diss., Univ. Orange Free State. Bloemfontein. $100 \mathrm{p}$.

12. Botha, B.J.V. (1986). The transition from the Kaapvaal Craton to the Namaqua Mobile Belt. In: Schoch, A.E., Van Aswegen, G., Colliston, W.P., Botha, B.J.V., Grobler, N.J., Geringer, G. \& Strydom, D. Excursion Guide book for Namaqualand (Excursion No. 24A). 2 lst Congr. Geol. Soc. S. Afr., (Johannesburg) 105 p. with map.

13. Colliston, W.P., Praekelt, H.E. \& Schoch, A.E. (1989). A broad perspective (Haramoep) of geological relations established by sequence mapping in the Proterozoic Aggeneys terrane, Bushmanland, South Africa. S. Afr. J. Geol., 92, 42-48.

14. Colliston, W.P., Praekelt, H.E. \& Schoch, A.E. (1989). Structural development and processes in the Proterozoic Namaqua mobile belt, South Africa: a progressive ductile shear model. Abstract, $28 \mathrm{th} / \mathrm{h}$ ternat. Geol. Congr. (Washington D.C.), 1, 314-315.

15. Colliston, W.P., Praekelt, H.E. \& Schoch, A.E. (in press). A progressive ductile shear model for the Proterozoic Aggeneys terrane. Namaqua mobile belt, Soulh Africa. Precambrian Res.

16. Joubert, P. (1986). Namaqualand - a model of Proterozoic Accretion? Trans. Geol. Soc. S. Afr., 89, 79-96.
17. Prackelt, H.E., Botha, B.J.V. \& Malherbe, S.J. (1986). Diskretc korsfragmente in die sentrale gedeelte van die Namakwagordel in die omgewing van Augrabies, Ann. Geol. Opn. S. Afr., 20, 25-40.

18. Schoch, A.E. \& Strydom, D. (1986). Moegabees (detailed map of the Naab thrust zone), 1:1000 map. In: Strydom, D. (Ed.). Colliston, W.P., Praekelt, H.E., Schoch. A.E., Van Aswegen, G., Pretorius, J.J., Beukes, G.J., Cilliers, B., Watkeys, M.K. and Botes, F.J. (1987). The tectonic units of parts of Namaqualand, Bushmanland and southern Southest Africa/Namibia; 1:250 000. Dept. Geology, Univ. Orange Free State (I sheel printed on both sides)

19. Stowe. C.W. (1986). Synthesis and interpretation of structures along the north-eastern boundary of the Namaqua tectonic province, South Africa, Trans. Geol. Soc. S. Afr., 89, 185-198.

20. Van Aswegen, G., Sirydom, D. Colliston. W. P., Prackelt, H.E. Schoch, A.E., Blignault, H.J., Botha. B.J.V. \& Van der Merwe, S.W. (1987). The structural-stratigraphic development of part of the Namaqua Metamorphic Complex - an example of Proterozoic major thrust tectonics. In: Kröner, A. ed. Proterozoic Lithospheric Eiolution. Amer. Geophys. Union Geodynamics Ser. . 17, 207-216.

21. Van der Merwe, S.W. \& Botha, B.J.V. (1989). Groothoek thrust belt in Western Namaqualand: an example of mid-crustal structure, $S$. Afr. J. Geol., 92, 155-166.

22. Gaal, G. (1984). World wide early to mid-Proterozoic correlations. Abstract. 27ih Internal. Geol. Congr. (Moscow) 9(1). 156.

23. Hoffman, P.F. (1989). Speculations on Luurentia's first gigayear (2.0 10 $1.0 \mathrm{Ga}$, Geology: 17, 135-138.

24. Kröner, A. (1989). Plate Motion, Crustal Accretion and Supercontinent Assemblage since the Early Archacan, Abstract, 28h Imternat. Geol. Congr., (Washington D.C.) 2. 230-231.

25. Crawtord, M.L. (1981). Fluid inclusions in metamorphic rocks - Low and medium grade. In: Hollister, L.S. and Crawford, M.L. eds. Short Course Handbook 6. Mineral Ass. Canada, (Calgary), 157-18I.

26. Hendel, E.M. \& Hollister, L.S. (1981). An empirical solvus for $\mathrm{CO}_{2}-\mathrm{H}_{2} \mathrm{O}-2,6 \mathrm{wt} \%$ salt. Geochim. Cosmochim. Acta, 45, 225-228. 


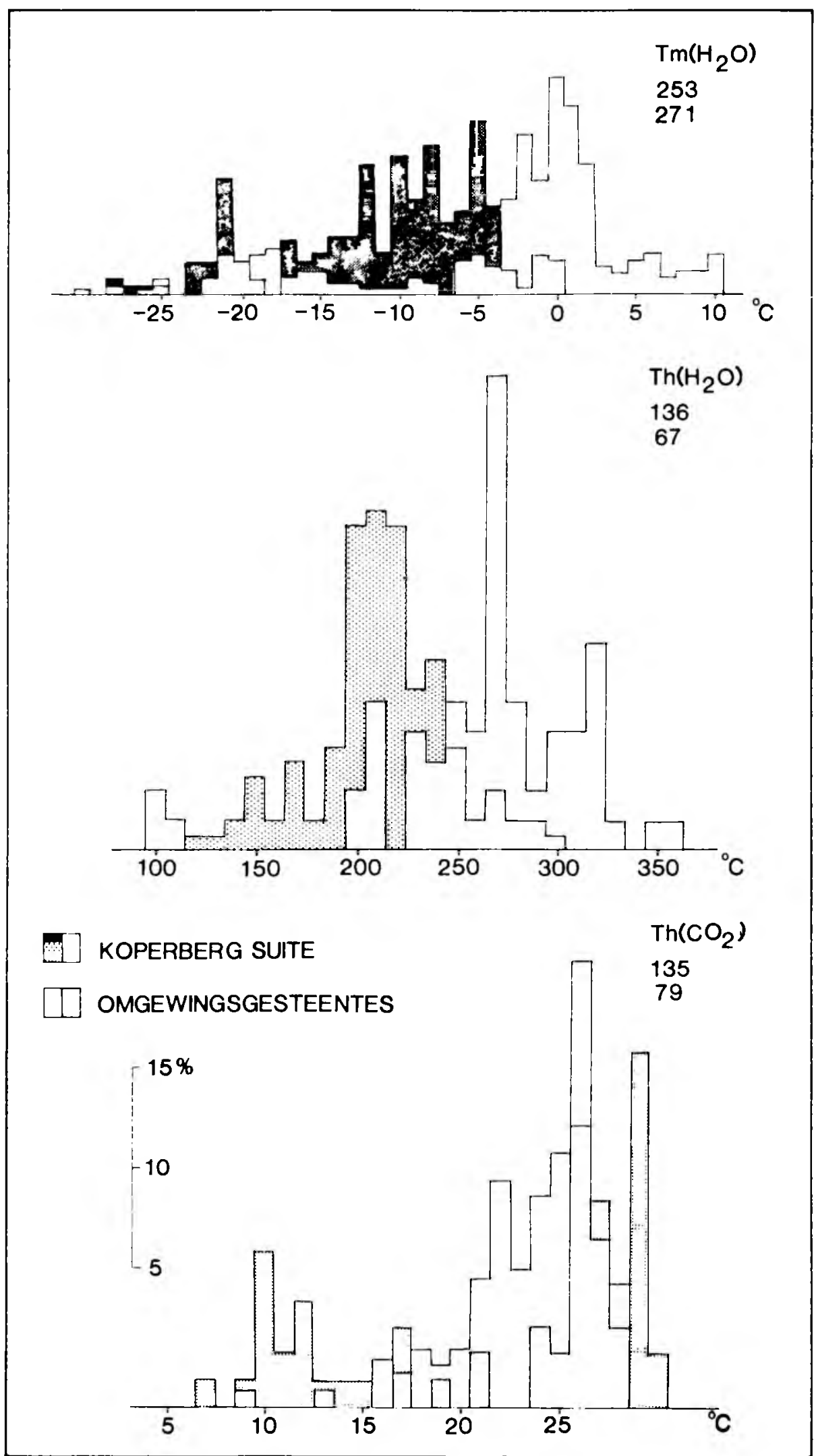

FIGUUR 13: Vergelyking tussen akkumulatiewe mikrotermometriese resultate vir lede van die Koperberg Suite, Namakwaland en omgewingsgesteentes. Van die twee getalle by elke histogram verteenwoordig die boonste een die aantal gedupliseerde lesings vir Koperberg Suite en die onderste een die ooreenstemmende waardes vir omgewingsgesteentes. 
27. Bowers, T.S. \& Helgeson, H.C. (1983). Calculation of the thermodynamic and geochemical consequences of nonideal mixing in the system $\mathrm{H}, \mathrm{O}-\mathrm{CO}_{2}-\mathrm{NaCI}$ on phase relations in geologic systems: Equation of state for $\mathrm{H}_{2} \mathrm{O}-\mathrm{CO}_{2}-\mathrm{NaCI}$ fluids at high pressures and temperatures, Geochim. Cosmochim. Acta, 47, 1247-1275.

28. Collins, P.L.F. (1979). Gas hydrates in $\mathrm{CO}_{2}$-bearing fluid inclusions and the use of freezing data for the estimation of salinity, Econ. Geol. $74,1435-1444$

29. Fisher, J.R. (1976). The volmetric properties of $\mathrm{H}_{2} \mathrm{O}$ - a graphical portrayal, J. Research U.S. Geol. Surv., 4, 189-193.

30. Hall, D.L., Sterner, M.S. \& Bodnar, R.J. (1988). Freezing point depression of $\mathrm{NaCl}-\mathrm{KCI}-\mathrm{H}_{2} \mathrm{O}$ solutions, Econ. Geol. , 83, 197-202.

31. Roedder, E., \& Bodnar, R.J. (1980). Geologic pressure determinations from fluid inclusion studies, Ann. Rev. Earth Planet. Sci., 8 , 263-301.

32. Heyen, G., Ramboz, C \& Dubessy, A. (1982). Simulation des équilibres dans le système $\mathrm{CO}_{2}-\mathrm{CH}_{4}$ en dessous de $50^{\circ} \mathrm{C}$ et de 100 bar. Applications aux inclusions fluides, C.R. Acad. Sci. Paris, 294, 203-206.

33. Angus, S., Armstrong, B., de Reuck, K.M., Altunin, V.V., Gadetskii, O.G., Chapela, G.A. \& Rowlinson, J.S. (1976). International Thermodynamic tables of the Fluid State: Vol. 3, Carbon Dioxide. Pergamon Press. 385 p.

34. Naumov, V.B. (1988). Volatile components in magmatic and metamorphic processes: fluid and melt inclusion data., Bull. Minéral., ll1, 291-296.

35. Naumov, V.B. \& Kovalenko, V.I. (1985). Volatile components of magmatic and metamorphic processes from data obtained during the study of inclusions in minerals (In Russian), Doklady Akad. Nauk. SSSR, $284,1461-1463$

36. Naumov, V.B. \& Kovalenko, V.I. (1985). A description of the principal volatile components of magmatic and metamorphic processes from data obtained during the study of inclusions in minerals (In Russian) Abstract in: Fluid Inclusion Research, 18, 290-291.

37. Yermakov (Jermakof), N.P., Naumov, V.B. \& Khitarov, D.N. (1984). Fluid inclusions in minerals and their significance in the study of hydrothermal ore formation, Abstract, 27th Internat. Geol. Congr. (Moscow) 5, 205-206.

38. Yermakov (Jermakof), N.P., Naumov, V.B. and Khitarov, D.N. (1984). Fluid inclusions in minerals and their significance in the study of hydrothermal ore formation, Proc. 27th Internat. Geol. Congr. (Moscow) 10, 185-203.

39. Klatı, E. (1980). Seriengliederung, mineralfazies und Zusammensetzung der Flüssigkeits-einschlüsse in der Präkambrischen Gesteinsserien Nordlapplands. Ph.D. diss., Univ. Kiel, 125 p

40. Klatt, E. \& Schoch, A.E. (1984). Comparison of fluid inclusion characteristics for high grade metamorphic rocks from Finnish Lapland with medium grade rocks from North-western Cape Province, South Africa, Abstract, 27th Internat. Geol. Congr. (Moscow) 5, 73

41. Colliston, W.P., Praekelt, H.E. \& Schoch, A.E. (1989). Authors" reply to discussion by J.H.W. Ward on 'A broad perspective (Haramoep) of geological relations established by sequence map- ping in the Proterozoic Aggeneys terrane, Bushmanland, South Africa' S. Afr. J. Geol., 92, 459-460.

42. Schoch, A.E., Colliston, W.P., Strydom, D., Praekelt, H.E. \& Van Aswegen, G. (1986). The metasediments of Bushmanland, Absiract, 21st Congr. Geol. Soc. S. Afr. (Johannesburg) 1, 861-865.

43. Strydom, D. (1985). 'n Struktureel-stratigrafiese studie van die metasedimente en ander metamorfiete van noordwestelike Boesmanland. Ongepubl. M.Sc. verhandeling, Universiteit van die OranjeVrystaat, 172 met gedrukte 1:100 000 kaart.

44. Strydom, D. \& Visser J.N.J (1986). Nappe structures in the highly deformed Proterozoic metasedimentary Aggeneys-type sequence of western Bushmanland, South Africa. Precambrian Research, 33 171-187.

45. Colliston, W.P. (Ed.), Praekelt, H.E., Strydom, D., Pretorius, J.J. \& Schoch, A.E. (Coord.) (1986). Stratigraphic Map of Central Bush manland (1:100 000 geological map), Depart. Geology, Univ. Orange Free State. One Sheet.

46. Praekelt, H.E., Colliston, W.P. \& Schoch, A.E. (1989). Authors' reply to discussion by P. Smith on 'A broad perspective (Haramoep) of geological relations established by sequence mapping in the Proterozoic Aggeneys terrane, Bushmanland, South Africa', $S$. Afr. J. Geol. , 92, 464-466.

47. Praekelt, H.E., Strydom, D., Colliston, W.P. \& Schoch, A.E. (in die pers). Die Hotson Formasie. SAKS Litostratigrafie Reeks.

48. Cilliers, F.H. (1987). Isotope characteristics of the sulphide-bearing sequence of the Areachap Group in the Boksputs area, Northwest Cape. Unpubl. M.Sc. diss. Univ. Orange Free State.

49. Pretorius, J.J. (1986). 'n Stratigrafiese en petrochemiese ondersoek van die Areachapgroep-gesteentes in die Boksputs omgewing met verwysing na kontroles vir sulfiedmineralisasie. Ongepubl. M.Sc. verhand., Universiteit van die Oranje-Vrystaat, Bloemfontein, $593 \mathrm{p}$.

50. Theart, H.F.J., Cornell, D.H. \& Schade, J. (1989). Geochemistry and metamorphism of the Prieska $\mathrm{Zn}-\mathrm{Cu}$ deposit, South Africa. Econ. Geol, , 84, 34-48.

5!. Voet, H.W. \& King, B.H. (1986). The Areachap copper-zinc deposit, Gordonia district. In: Anhaeusser, C.R. \& Maske, S., (Eds.), Mineral Deposits of Southern Africa, 2, 1529-1537. Geol. Soc. S. Afr., Johannesburg. 2 volumes.

52. Conradie, J.A. \&. Schoch, A.E. (1986). Petrochemical characteristics of the Koperberg Suite, South Africa - an analogy to massiftype anorthosites? Precambrian Research, 31, 157-188.

53. Conradie, J.A. \& Schoch, A.E. (1988). Rare earth element geochemistry of an anorthosite-diorite suite, Namaqua mobile belt, South Africa. Earth Planet. Sci. Lett., 87, 409-422.

54. Schoch, A.E. \& Conradie, J.A. (1990). Petrochemical and mineralogical relationships in the Koperberg Suite, Namaqualand, South Africa. Amer. Miner, 75, 27-36.

55. Boer, R.H. (1989). The petrogenesis of the glimmerite occurrences in the Koperberg Suite, Namaqualand. Unpubl. M.Sc. diss. Univ. Orange Free State. $183 \mathrm{p}$

56. Nicholls, J. \& Crawford, M.L. (1985). Fortran programmes for calculation of fluid properties from microthermometric data on fluid inclusions, Computers and Geosciences, I1, 619-645. 